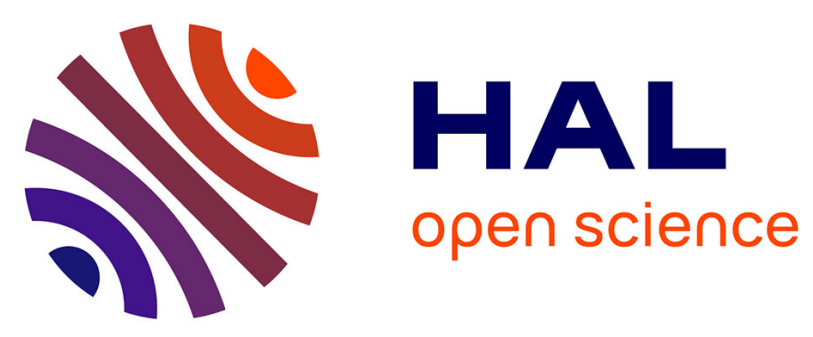

\title{
A multiproxy assessment of the western equatorial Pacific hydrography during the last $30 \mathrm{kyr}$
}

Thibault Garidel-Thoron, Yair Rosenthal, Luc L Beaufort, Edouard Bard, Corinne Sonzogni, Alan C. Mix

\section{- To cite this version:}

Thibault Garidel-Thoron, Yair Rosenthal, Luc L Beaufort, Edouard Bard, Corinne Sonzogni, et al.. A multiproxy assessment of the western equatorial Pacific hydrography during the last 30 kyr. Paleoceanography, 2007, 22 (3), 10.1029/2006PA001269 . hal-01458327

\section{HAL Id: hal-01458327 \\ https://hal.science/hal-01458327}

Submitted on 19 Aug 2021

HAL is a multi-disciplinary open access archive for the deposit and dissemination of scientific research documents, whether they are published or not. The documents may come from teaching and research institutions in France or abroad, or from public or private research centers.
L'archive ouverte pluridisciplinaire HAL, est destinée au dépôt et à la diffusion de documents scientifiques de niveau recherche, publiés ou non, émanant des établissements d'enseignement et de recherche français ou étrangers, des laboratoires publics ou privés.

$$
\text { Copyright }
$$




\title{
A multiproxy assessment of the western equatorial Pacific hydrography during the last $30 \mathrm{kyr}$
}

\author{
Thibault de Garidel-Thoron, ${ }^{1,2}$ Yair Rosenthal, ${ }^{1,3}$ Luc Beaufort, ${ }^{2}$ Edouard Bard, ${ }^{2}$ \\ Corinne Sonzogni, ${ }^{2}$ and Alan C. Mix ${ }^{4}$
}

Received 9 January 2006; revised 21 November 2006; accepted 1 February 2007; published 26 July 2007.

[1] Sea surface temperature (SST) and salinity of the Western Pacific Warm Pool (WPWP) reflect global climate effects such as the El Niño-Southern Oscillation phenomenon. However, reconstructions of past changes in the WPWP from the geologic record vary depending on the specific proxy record used. Here we develop a multiproxy record of the last deglaciation from a radiocarbon-dated sediment core (MD97-2138) retrieved in the heart of the WPWP. SST reconstructions for the past 30,000 years based on planktonic foraminiferal $\mathrm{Mg} / \mathrm{Ca}$ (Globigerinoides ruber and Globigerinoides sacculifer), alkenone unsaturation index, and foraminiferal transfer functions differ notably. $\mathrm{Mg} / \mathrm{Ca}$-based SST estimates from the surface dwelling species G. ruber in MD97-2138 indicate a larger surface cooling $\left(3^{\circ} \pm 0.6^{\circ} \mathrm{C}\right)$ during the Last Glacial Maximum (LGM) than inferred from $\mathrm{Mg} / \mathrm{Ca}$ ratios in $\mathrm{G}$. sacculifer $\left(2.3^{\circ} \pm 0.7^{\circ} \mathrm{C}\right)$, statistical transfer functions based on planktonic foraminiferal species assemblages, and $\mathrm{Uk}_{37}^{\prime}\left(1^{\circ}-2^{\circ} \mathrm{C}\right)$. These estimates are consistent with estimates from other WPWP cores, thereby suggesting that the discrepancy is due to proxy compatibility rather than differences in cores qualitity. Postdepositional dissolution above the lysocline might have altered the $\mathrm{Mg} / \mathrm{Ca}$-based temperature estimates in our site, but this effect is insufficient to resolve discrepancies between $\mathrm{Mg} / \mathrm{Ca}$ in $\mathrm{G}$. ruber and the other proxies. We suggest that the lower estimates obtained from $\mathrm{Mg} / \mathrm{Ca}$ in $\mathrm{G}$. sacculifer, faunal transfer functions, and $\mathrm{Uk}_{37}^{\prime}$ might reflect subsurface temperature changes rather than strict surface estimates. Accounting for potential artefacts, including dissolution and bioturbation, we suggest that the glacial WPWP SST was about $2.5^{\circ} \pm 0.7^{\circ} \mathrm{C}$ cooler than during the Holocene, whereas the subsurface/upper thermocline temperature change was only about $1.8^{\circ} \pm 0.7^{\circ} \mathrm{C}$. Interpreting variations in $\delta^{18} \mathrm{O}_{\mathrm{Sw}}$ in terms of salinity changes suggests a possibly slight decrease in surface salinity at the site of MD97-2138 during the LGM. Though LGM freshening in MD97-2138 is not robust to postdeposition dissolution effects, this inferred freshening appears to be a general feature of the western equatorial Pacific.

Citation: de Garidel-Thoron, T., Y. Rosenthal, L. Beaufort, E. Bard, C. Sonzogni, and A. C. Mix (2007), A multiproxy assessment of the western equatorial Pacific hydrography during the last $30 \mathrm{kyr}$, Paleoceanography, 22, PA3204, doi:10.1029/2006PA001269.

\section{Introduction}

[2] The sensitivity of the equatorial ocean to changes in radiative forcing, caused by variations in atmospheric $p \mathrm{CO}_{2}$, is an important question in climate research. Of special interest is the Western Pacific Warm Pool (WPWP), with the warmest waters of the global ocean, whose past changes remains poorly constrained. The WPWP is a major source of water vapor to the troposphere [Pierrehumbert, 2000]. It plays a key role in the strength of the east Asian monsoon [Webster et al., 1998], and Walker atmospheric

\footnotetext{
${ }^{1}$ Institute of Marine and Coastal Sciences, Rutgers the State University of New Jersey, New Brunswick, New Jersey, USA.

${ }^{2}$ Centre Européen de Recherche et d'Enseignement de Géosciences de l'Environnement, Centre National de la Recherche Scientifique, AixMarseille Université-Europôle Méditerranéen de l'Arbois, Aix-enProvence, France.

${ }^{3}$ Department of Geology, Rutgers the State University of New Jersey, New Brunswick, New Jersey, USA.

${ }^{4}$ College of Oceanography and Atmospheric Sciences, Oregon State University, Corvallis, Oregon, USA.
}

Copyright 2007 by the American Geophysical Union. 0883-8305/07/2006PA001269 circulation, thus exerting a critical influence on the El NiñoSouthern Oscillation (ENSO) phenomenon. Under current conditions, interannual variations in the distribution of equatorial sea surface temperature (SST), related to ENSO variability, exert a major effect on atmospheric circulation and global climate [e.g., Halpert and Ropelewski, 1992; Ropelewski and Halpert, 1989]. Likewise, longer-term changes of SST patterns in the equatorial Pacific might also have had large consequences for tropical and extratropical climate during the last glacial maximum (LGM) [Hostetler and Mix, 1999; Yin and Battisti, 2001].

[3] General circulation model studies suggest a relatively uniform cooling of tropical SST in response to extratropical forcing during the LGM [Andreasen et al., 2001; Hewitt et al., 2003; Kim et al., 2003; Shin et al., 2003]. Simpler process models suggest, however that decreased seasonality associated with reduced summer insolation, would favor a shift in the mean climate state of the equatorial Pacific to more El Niño-like conditions during the last deglaciation relative to the modern climate state [Clement et al., 1999]. Modern El Niño-related variations in the equatorial Pacific are mainly characterized by three major hydrographic 
changes: (1) a decrease in the east-west equatorial Pacific zonal SST gradient due to anomalous warming of the eastern equatorial Pacific cold tongue; (2) a deepening of the equatorial Pacific thermocline in the east and shoaling in the west; and (3) an eastward migration of the precipitation cell from the western to the central and eastern Pacific. The sedimentary evidence for past changes in these hydrographic parameters is, however, controversial arguing for more El Niño-like or La Niña-like conditions, depending on the specific methodology. Regardless of the results, these analogies pertain only to changes in the equatorial Pacific mean climate state and not to changes within the interrannual band.

[4] Two opposite climate states have been suggested for the glacial equatorial Pacific Ocean. First, Koutavas et al. [2002], using $\mathrm{Mg} / \mathrm{Ca}$ paleothermometry has argued for weakening of SST gradients within the cold tongue of the eastern equatorial Pacific during the Last Glacial Maximum (LGM) in a pattern consistent with "El Niño-like" conditions. In contrast, transfer functions used to infer the depth of thermocline and SSTs in the eastern Pacific indicate both an enhancement of the zonal thermocline tilt (deepening in the WPWP, shoaling in the cold tongue) [Andreasen and Ravelo, 1997] and relatively large cooling of eastern Pacific surface water, in accord with an increase in upwelling in this region [Feldberg and Mix, 2003; Mix et al., 1999]. In the eastern equatorial Pacific, changes in SST are the best indicator for paleo-ENSO related variability. In the modern WPWP, however, changes in surface salinity associated with net precipitation provide a more pronounced signal. Yet, it is still debated whether the regional salinity was lower or higher during the LGM [de Garidel-Thoron et al., 2005; Lea et al., 2000; Martinez et al., 1997; Rosenthal et al., 2003; Stott et al., 2002], which has important ramifications for the discussion whether the glacial Pacific was in a more La Niña or El Niño-like mode during the LGM. A major source of contention in this debate is the fidelity of the proxies, or the cores used in each study. Clearly, a large part of the uncertainty as to the status of the glacial Pacific Ocean must be associated with methodological differences among the different proxy records.

[5] Here we use the alkenone unsaturation index, planktonic foraminiferal $\delta^{18} \mathrm{O}, \mathrm{Mg} / \mathrm{Ca}$ and transfer functions from a core in the WPWP, MD97-2138 $\left(1^{\circ} 25^{\prime} \mathrm{S}, 146^{\circ} 24^{\prime} \mathrm{E}\right.$, $1900 \mathrm{~m}$ deep) (Figures $1 \mathrm{a}$ and $1 \mathrm{~b}$ ), to document past changes in sea surface temperature, salinity and thermocline depth of the WPWP during the last 30,000 years. Comparing multiple proxy results from a single well-dated core allows us to determine potential biases of each specific methodology. We combine our new results with previously published records to reconstruct variations in WPWP hydrography during the last glacial termination, and assess whether these changes in the mean climate state of the equatorial Pacific are consistent with the proposed analogies to the modern interrannual ENSO variability.

\section{Modern ENSO Signatures in the Western Pacific Warm Pool}

[6] The ENSO phenomenon can be described as a zonal oscillator within the equatorial Pacific: During El Niño phase of ENSO, the trade winds weaken, warm western Pacific surface waters are displaced eastward leading to higher SSTs in the eastern Pacific, and the zonal thermocline tilt relaxes. In the WPWP, an El Niño phase is characterized by a slight cooling in the surface $\left(\sim 0.5^{\circ} \mathrm{C}\right)$, a strong decrease in precipitation, a marked increase in surface salinity, and shoaling of the thermocline (Figures 1c and 1d) [e.g., Delcroix and McPhaden, 2002; Fedorov and Philander, 2000]. Conversely, during La Niña events, there is a small increase in WPWP SSTs, a large increase in precipitation, freshening of surface water, and deepening of the western equatorial Pacific thermocline. This canonical scheme is exemplified by the 1997-1998 El Niño event as observed from the Tropical Ocean-Global AtmosphereTropical Atmosphere Ocean project mooring data sets (Figures 1c and 1d). At the closest mooring site to MD972138 location, the El Niño event is characterized by a slight surface cooling $\left(\sim 0.5^{\circ} \mathrm{C}\right)$, and $\sim 50 \mathrm{~m}$ shoaling of the thermocline.

[7] In order to illustrate the links between precipitation and El Niño, we computed a regression analysis between the NASA precipitation time series (1979-2001), and the NINO-3 temperatures during this period (Figure 1b). At the MD97-2138 site, positive NINO-3 anomalies (corresponding to El Niño events) are correlated with a strong deficit in precipitation, an increase in surface salinity of the westernmost part of the warm pool (near MD97-2138 and MD972140 sites), but freshening of the easternmost region, the so-called fresh pool, where Ocean Drilling Program (ODP) site 806 is located [Delcroix and McPhaden, 2002] (Figure $1 \mathrm{~b}$ and Table 1). These trends are reversed during

\footnotetext{
Figure 1. Comparison of the modern climatological sea surface temperatures (a) from the World Ocean Atlas 1998 [Conkright et al., 1998] with (b) precipitation anomalies associated with the NINO3 index. The precipitation anomalies were computed using a regression between the NASA satellite time series of precipitations from 1979 to 2001 (Global Positioning Climatology Project Version 2 Combined Precipitation Data Set) and the NINO3 index (National Centers for Environmental Prediction NINO3), both data sets from Lamont-Doherty Earth Observatory/International Research Institute for Climate and Society Data Library. The front between the westernmost part of the Western Pacific Warm Pool and the eastern warm pool-fresh pool is located at about $160^{\circ} \mathrm{E}$. The location of cores discussed in the text is displayed. Both MD97-2138 and MD97-2140 cores are located in the warm pool, characterized by drier than average conditions during El Niño events (positive NINO3 anomalies) in contrast with the increased precipitation at ODP 806 site during El Niño events. (c) Sea surface temperature and (d) thermal upper ocean time series from the Tropical Ocean-Global AtmosphereTOA mooring at $147^{\circ} \mathrm{E}$ on the equator. The $1997-1998 \mathrm{El}$ Niño event is marked by cooling larger than seasonal variations and by an about $50 \mathrm{~m}$ shoaling of the thermocline depth (bold line is $18^{\circ} \mathrm{C}$ isothermal).
} 
Longitude

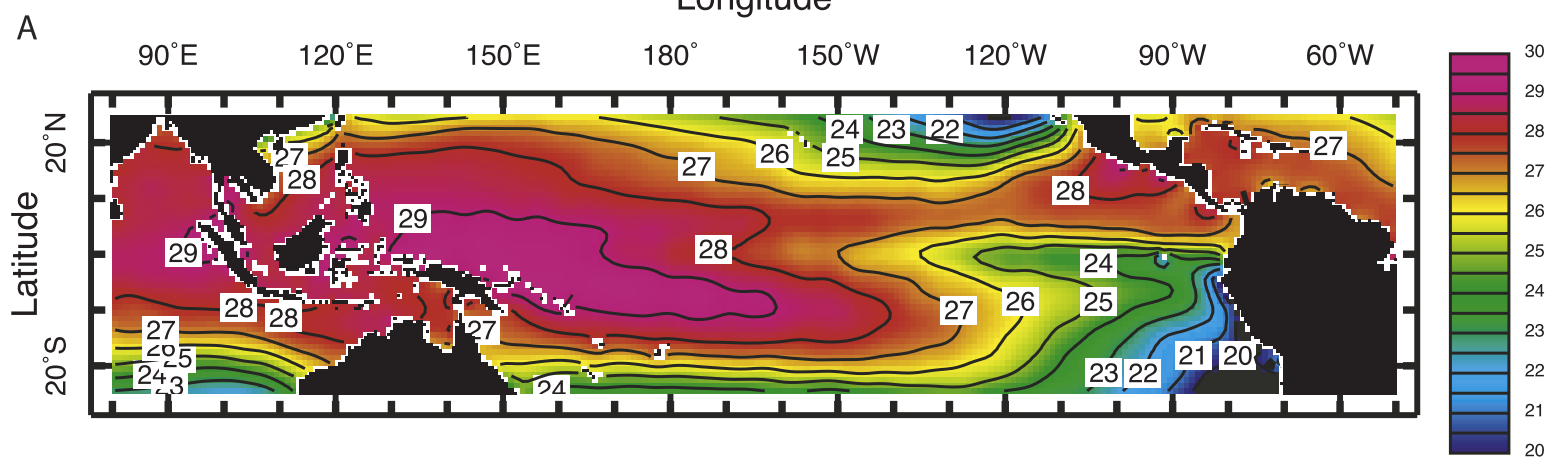

B
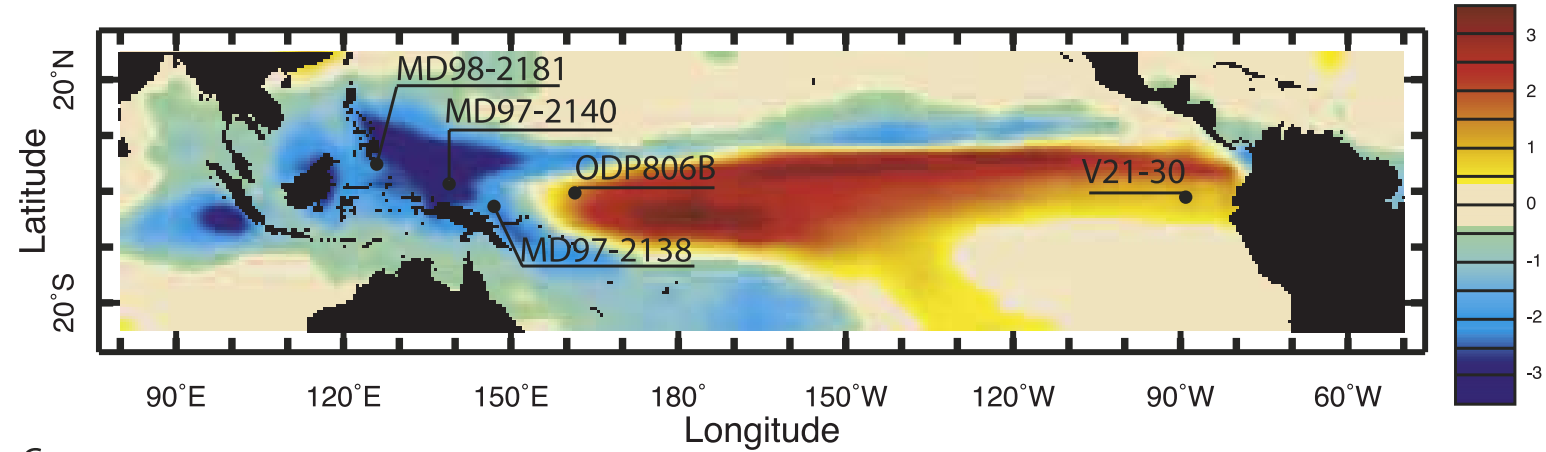

C
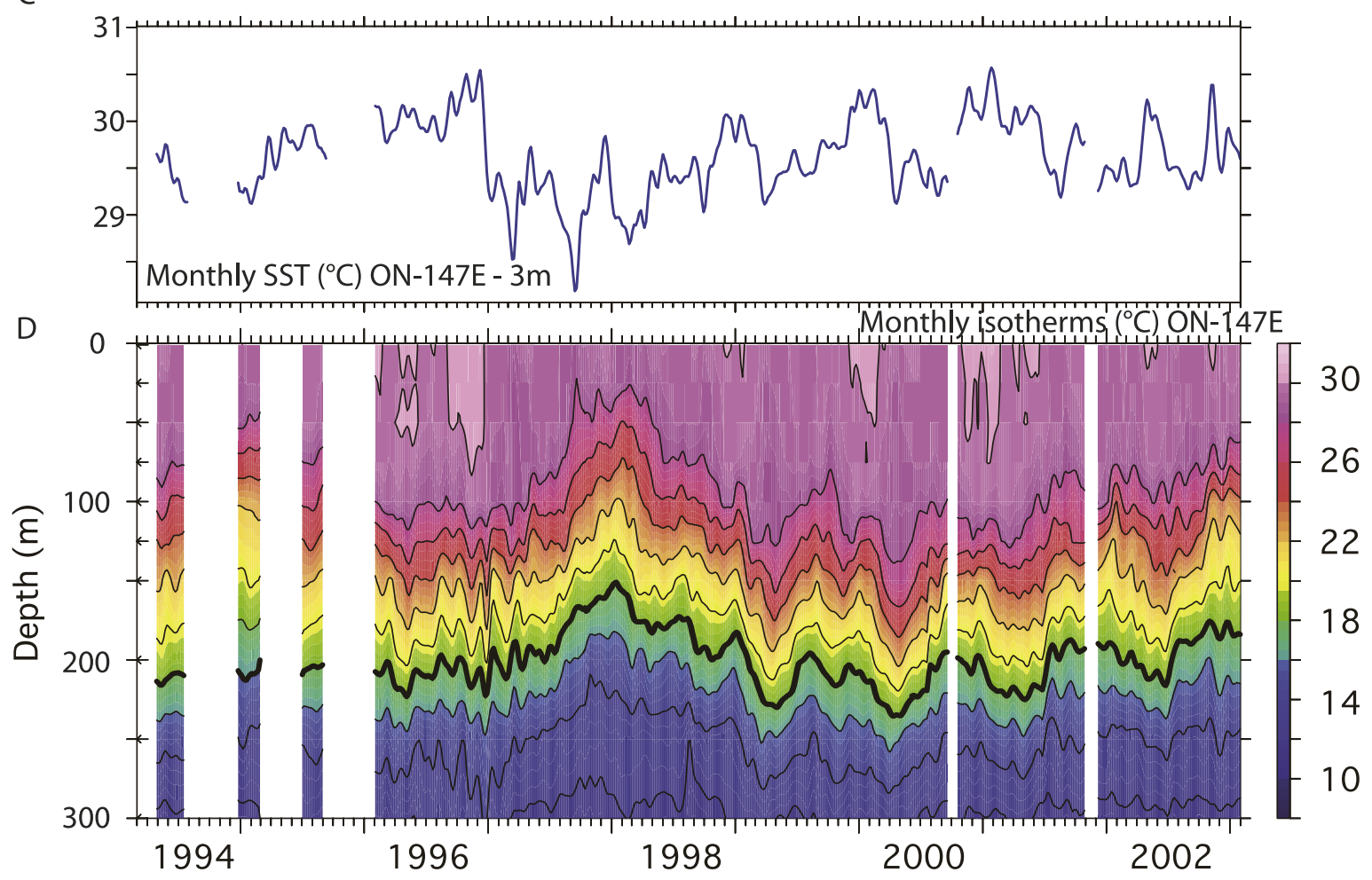

Figure 1 
Table 1. Location and Mean Climatology of the Cores Discussed in this Study

\begin{tabular}{|c|c|c|c|c|c|c|}
\hline Core & Longitude & Latitude & Depth, $\mathrm{m}$ & $\begin{array}{l}\text { Sedimentation } \\
\text { Rate, } \mathrm{cm} / \mathrm{kyr}\end{array}$ & $\begin{array}{l}\text { Climatological } \\
\text { Modern SST, }{ }^{\circ} \mathrm{C}\end{array}$ & References \\
\hline MD97-2138 & $146.14^{\circ} \mathrm{E}$ & $1.25^{\circ} \mathrm{N}$ & 1960 & 11 & $29.3( \pm 0.6)$ & this study \\
\hline MD97-2140 & $141.45^{\circ} \mathrm{E}$ & $2.02^{\circ} \mathrm{N}$ & 2547 & 8 & $29.3( \pm 0.7)$ & de Garidel-Thoron et al. [2005] \\
\hline ODP-806B & $159.21^{\circ} \mathrm{E}$ & $0.19^{\circ} \mathrm{N}$ & 2560 & 3 & $29.3( \pm 0.6)$ & $\begin{array}{l}\text { Lea et al. }[2000] \text { and } \\
\text { Dekens et al. }[2002]\end{array}$ \\
\hline MD97-2141 & $121.30^{\circ} \mathrm{E}$ & $8.8^{\circ} \mathrm{N}$ & 3600 & 22 & $28.7( \pm 2.7)$ & Rosenthal et al. [2003] \\
\hline MD98-2181 & $125.83^{\circ} \mathrm{E}$ & $6.3^{\circ} \mathrm{N}$ & 2114 & 63 & $28.9( \pm 1.6)$ & Stott et al. [2002] \\
\hline MD98-2162 & $117.54^{\circ} \mathrm{E}$ & $4.41^{\circ} \mathrm{S}$ & 1855 & 48 & $28.8( \pm 2.5)$ & Visser et al. [2003] \\
\hline $\mathrm{RC} 17-177$ & $159.45^{\circ} \mathrm{E}$ & $1.75^{\circ} \mathrm{N}$ & 2600 & 5 & $29.3( \pm 0.6)$ & $\begin{array}{l}\text { Billups and Schrag [2000] and } \\
\text { de Villiers [2003] }\end{array}$ \\
\hline ERDC-92 & $159.98^{\circ} \mathrm{E}$ & $2.33^{\circ} \mathrm{S}$ & 1598 & 1 & $29.3( \pm 0.5)$ & Palmer and Pearson [2003] \\
\hline RC10-140 & $156.97^{\circ} \mathrm{E}$ & $2.65^{\circ} \mathrm{S}$ & 1600 & 2 & $29.3( \pm 0.6)$ & de Villiers [2003] \\
\hline KH92-1-5cBX & $141.78 \mathrm{E}$ & $3.48^{\circ} \mathrm{N}$ & 2282 & 1 & $29.3( \pm 0.8)$ & Ohkouchi et al. [1994] \\
\hline
\end{tabular}

${ }^{\mathrm{a}}$ Climatological mean sea surface temperature (SST) from annual SST in WOA2001 (seasonal range computed as the maximum range in SST during the climatological year from WOA01).

La Niña events. In contrast with the MD97-2138 site where the main contributor of variance to the historical salinity time series is the freshening associated with La Niña, the Mindanao Sea site of MD98-2181 studied by Stott et al. [2002], displays surface salinity variability associated with changes in east Asian monsoon rather than ENSO.

\section{Methods}

\subsection{Stratigraphy, Stable Isotopes, and $\mathrm{Mg} / \mathrm{Ca}$} Measurements

[8] The MD97-2138 stratigraphy is based on 6 AMS ${ }^{14} \mathrm{C}$ dates and the oxygen isotope record. Radiocarbon ages were determined on G. ruber (white) and were performed at the AMS Tandetron facility in Gif/Yvette facility (Table 2). The ${ }^{14} \mathrm{C}$ ages were converted to calendar ages using the INTCAL98 calibration (1998) for the last 18,000 years and the polynomial fit of Bard [1998] for ages prior to the period covered by the INTCAL98 study.

[9] Stable isotopes and $\mathrm{Mg} / \mathrm{Ca}$ measurements were carried out on two surface to subsurface dwelling planktonic foraminifera species, Globigerinoides ruber (white s.s. in the sense of Wang [2000], 250-300 $\mu \mathrm{m}$ fraction) and Globigerinoides sacculifer (without sac; $355-455 \mu \mathrm{m}$ fraction). Typically, 10 to 15 shells were analyzed for stable isotope measurements and about 20 to 30 for trace metal analyses. Stable isotope measurements were performed at the Oregon State University facility using a Finnigan/MAT 251 mass spectrometer, with external precision of $0.06 \%$ for $\delta^{18} \mathrm{O} . \mathrm{Mg} / \mathrm{Ca}$ measurements were done at Rutgers University using Finnigan Element 1 ICP-MS, following the analytical protocol detailed by Rosenthal et al. [1999]. Samples were prepared using a short version of the Boyle and Keigwin [1985] method, which excludes the reductive step. The long-term external precision of $\mathrm{Mg} / \mathrm{Ca}$ analysis was about $1.6 \%(1 \sigma \mathrm{RSD})$ as determined by repeated measurements of three consistency standards with $\mathrm{Mg} / \mathrm{Ca}$ ratios varying from $\sim 1.2$ to $7 \mathrm{mmol} \mathrm{mol}{ }^{-1}$. This is equivalent to approximately $\pm 0.2^{\circ} \mathrm{C}$ analytical error in the down core record. The accuracy of our procedure has been validated within the framework of a recent international $\mathrm{Mg}$ / Ca intercomparison study [Rosenthal et al., 2004].

\subsection{Foraminiferal Transfer Functions}

[10] Foraminifera for assemblages reconstruction were picked from the $>150 \mu \mathrm{m}$ fraction. The classical ImbrieKipp transfer functions [Imbrie and Kipp, 1971] are based on a $\mathrm{Q}$ mode factor analysis of modern foraminiferal species counts, which are regressed against oceanic parameters. We use this method to reconstruct two parameters of the water column: (1) sea surface temperature and (2) thermocline depth.

[11] We use the original transfer functions devised to reconstruct Pacific SST, so-called FP12-E equations [Moore et al., 1980b], which were calibrated against winter and summer SSTs, for assessing the CLIMAP SSTs versus recent estimates based on new geochemical SST proxies. We note, however, that other statistical formulations, and selection of alternate core top databases, may yield slightly different transfer function temperature estimates. Reassessing transfer functions in the equatorial WPWP is beyond the scope of this manuscript, and has been discussed elsewhere [e.g., Chen et al., 2005b]. Differences between the various statistical methods are generally within the calibration error $\left(<1^{\circ}-2^{\circ} \mathrm{C}\right)$ for late Quaternary equatorial Pacific reconstructions [Chen et al., 2005a].

Table 2. Radiocarbon Ages Used to Establish MD97-2138 Chronology

\begin{tabular}{cccccc}
\hline $\begin{array}{l}\text { Depth in } \\
\text { Core, } \mathrm{cm}\end{array}$ & $\begin{array}{c}\text { AMS }{ }^{14} \mathrm{C} \\
\text { Age, years }\end{array}$ & $\begin{array}{c}\text { Error, } \\
\text { years }\end{array}$ & $\begin{array}{c}\text { Calendar } \\
\text { Age, years }\end{array}$ & Species & $\begin{array}{c}\text { Accession } \\
\text { Number }\end{array}$ \\
\hline 1 & 3,350 & 60 & 3,208 & G. ruber (white) & GifA-101001 \\
65 & 9,210 & 90 & 9,830 & G. ruber (white) & GifA-101002 \\
101 & 11,790 & 110 & 13,177 & G. ruber (white) & GifA-101003 \\
165 & 15,630 & 140 & 18,090 & G. ruber (white) & GifA-101004 \\
220 & 19,420 & 150 & 22,451 & G. ruber (white) & GifA-101005 \\
280 & 25,030 & 230 & 28,930 & G. ruber (white) & GifA-101006 \\
\hline
\end{tabular}


[12] In order to assess past changes in the thermocline depth, we apply the equation developed by Andreasen and Ravelo [1997] to MD97-2138 downcore foraminiferal assemblages. The extent of foraminiferal shell dissolution was assessed using the fragmentation index of the planktonic foraminifera, which divides the number of foraminiferal fragments by the number of complete shells (Figure 2) [Berger, 1971].

\subsection{Alkenone Measurements}

[13] Alkenones were analyzed at CEREGE by gas chromatography following the method described by Sonzogni et al. [1997] except that an automated Dionex Accelerated Solvent Extractor (ASE-200) was used to perform lipid extraction. Proper identification and quantification of alkenones was verified by gas chromatography mass spectrometry. The analytical precision of the method is about 0.01 units for $\mathrm{Uk}_{37}^{\prime}$ (roughly equivalent to $0.3^{\circ} \mathrm{C}$ ) based on repeated extraction of internal laboratory sediment standard during the the course of this study. The accuracy of our procedure has been checked within the framework of the international alkenone intercomparison [Rosell-Mélé et al., 2001].

\section{Results}

\subsection{Western Pacific Warm Pool SSTs Derived From Foraminiferal $\mathrm{Mg} / \mathrm{Ca}$}

[14] The $\delta^{18} \mathrm{O}_{G \text {. ruber }}$ record from MD98-2138 shows a $1.2 \%$ LGM to Holocene negative shift (Figure 2, LGM is defined as the interval of 18-24 kyr B.P. [Mix et al., 2001]). The $\delta^{18} \mathrm{O}_{G \text {. sacculifer }}$ record shows a larger LGM to Holocene shift of about $1.4 \%$. The LGM-Holocene $\Delta \mathrm{Mg} / \mathrm{Ca}_{G}$. ruber amplitude in MD-97-2138 is about $1.2 \mathrm{mmol} / \mathrm{mol}$, whereas the $\Delta \mathrm{Mg} / \mathrm{Ca}_{G \text {. sacculifer }}$ amplitude is $0.8 \mathrm{mmol} / \mathrm{mol}$.

[15] During the last $30 \mathrm{kyr}, \delta^{18} \mathrm{O}$ values in G. ruber are on average lower than those in $G$. sacculifer by about $0.4 \%$. $\mathrm{Mg} / \mathrm{Ca}$ in $G$. ruber is about $0.2 \mathrm{mmol} / \mathrm{mol} \mathrm{higher} \mathrm{than}$ G. sacculifer between 30 and $22 \mathrm{ka}$, and about $1 \mathrm{mmol} / \mathrm{mol}$ between $22 \mathrm{ka}$ and the core top. While the amplitude of interspecific difference in $\mathrm{Mg} / \mathrm{Ca}$ changes through time, the difference remains systematically positive. $\mathrm{Mg} / \mathrm{Ca}$ and $\delta^{18} \mathrm{O}$ offsets coherently suggest that $G$. ruber tests record physical conditions in the uppermost part of the water column and $G$. sacculifer preferentially indicate a deeper, subsurface habitat.

[16] Although it was argued that differences in the isotopic and $\mathrm{Mg} / \mathrm{Ca}$ composition of the two species might be due to differences in their seasonal growth period [Stott et al., 2002], there is no evidence for a preferential seasonal nor interranual pattern of production and sedimentation for these species in the western Pacific [Kawahata et al., 2002]. Moreover, it appears unlikely that these different geochemical signatures reflect regional preferences of $G$. sacculifer and $G$. ruber as these two species generally coexist in the subtropical ocean [e.g., Hemleben et al., 1989], and were observed in the same plankton nets from the western Pacific warm pool (T. de Garidel-Thoron, unpublished data, 2003). Instead, these differences are more likely the result of specific depth habitat preferences.
Evidence from the eastern equatorial Pacific indicates that G. ruber s.s. is a strict surface dweller, and suggests a deeper habitat of $G$. sacculifer (without sac), ranging within the mixed layer and upper thermocline depth [Spero et al., 2003]. Sequential leaching analysis of $\mathrm{Mg} / \mathrm{Ca}$ in these species also reveals little chemical heterogeneity in $G$. ruber, suggesting a narrow range of calification near the sea surface, but significant heterogeneity in G. sacculifer, indicating partial calification at cooler, subsurface, depths [Benway et al., 2003; Klinkhammer et al., 2004]. These studies support our interpretations for a limited, but significant vertical segregation of these two species in the water column, though field studies are needed to clarify this distribution.

[17] Field and laboratory calibrations suggest that all planktonic foraminifera species, studied to date, exhibit similar temperature sensitivity of $\mathrm{Mg} / \mathrm{Ca}$, ranging from 7 to 10 per degree Celsius [Anand et al., 2003; Dekens et al., 2002; Elderfield and Ganssen, 2000; Lea et al., 1999, 2000; McConnell and Thunell, 2005; Nürnberg et al., 1996]. In contrast, the preexponential coefficient varies among the species [Anand et al., 2003; Elderfield and Ganssen, 2000] and is also altered by selective postdepositional dissolution of shells [Rosenthal and Lohmann, 2002]. Rosenthal and Lohmann [2002] suggested using the shell weight as a correction factor for dissolution. Likewise, Dekens et al. [2002] proposed a dissolution correction, which depends either on the core depth or the bottom water carbonate saturation state. Both approaches, while applicable for recent sediments in which the extent of dissolution is reasonably well known, cannot be used, however, to correct for poorly known down-core changes in dissolution intensity.

[18] To calculate temperatures from $\mathrm{Mg} / \mathrm{Ca}$ we use the equation of $\mathrm{Mg} / \mathrm{Ca}=0.30 \exp (0.095 * \mathrm{SST})$, which was used in the study of the near by core MD97-2140 [de Garidel-Thoron et al., 2005]. The coefficient values are based on the following rationale:

[19] 1. The choice of an exponential value of 0.095 follows the work of Rosenthal and Lohmann [2002] which reassessed the core top $\mathrm{Mg} / \mathrm{Ca}$ data set developed by Elderfield and Ganssen [2000]. Though this exponential one is in the upper range of the one used in many calibration studies, we note that it is close to the 0.101 value obtained by Anand et al. [2003] on G. ruber white $(250-350 \mu \mathrm{m})$ from the Sargasso sea. Furthermore, a recent sediment trap study from the Guaymas Basin indicated that the temperature sensitivity of $\mathrm{Mg} / \mathrm{Ca}_{\text {G.ruber }}$ in the higher range of temperatures was slightly decreased reaching a preexponential value of 0.110 in the warmest temperature range observed $\left(30^{\circ}-33^{\circ} \mathrm{C}\right)$ [McConnell and Thunell, 2005].

[20] 2. We choose the same preexponential constant for both species, based on the fit between measured core top $\delta^{18} \mathrm{O}$ and $\mathrm{Mg} / \mathrm{Ca}$ and predicted values from the modern hydrography in this region (Figure 3). Although the absence of late Holocene sediments prevents us from directly comparing predicted values of $\delta^{18} \mathrm{O}$ and $\mathrm{Mg} / \mathrm{Ca}$, calculated from the modern hydrography, with recent sediment values for both species, we assume that the vertical range of calcification depths of $G$. ruber and $G$. sacculifer did not 


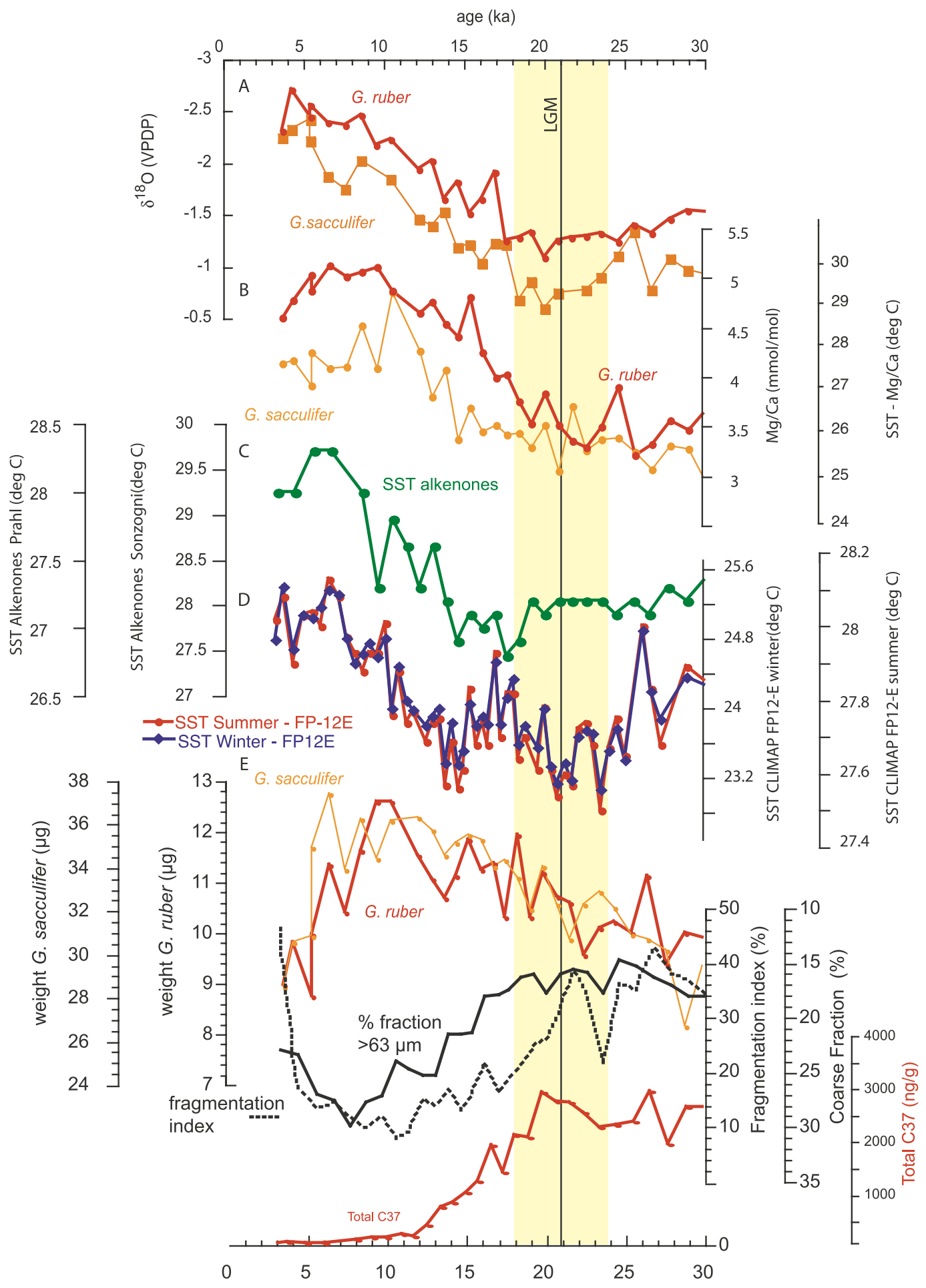

Figure 2. The 30 kyr multiproxy records from Western Pacific Warm Pool MD97-2138 core: (a) $\delta^{18} \mathrm{O}$ in planktonic foraminifera G. ruber (red line) and G. sacculifer (orange); (b) $\mathrm{Mg} / \mathrm{Ca}$ composition of planktonic foraminifera G. ruber (red line) and G. sacculifer (orange line); (c) alkenones-based temperature (green line) estimates using two different equations from Prahl et al. [1988] and Sonzogni et al. [1997]; (d) planktonic foraminifera temperature estimates from CLIMAP FP-12E transfer function with both winter (blue line) and summer (red line) scales; and (e) dissolution indices: shell weight of the planktonic foraminifera G. ruber (red line) and G. sacculifer (orange line), planktonic foraminifera fragmentation index (black dashed line), coarse fraction defined as the percentage of sediments coarser than $63 \mu \mathrm{m}$ (black solid line), total C37 concentration (ng/g) (red line). The shaded area corresponds to the Last Glacial Maximum period as defined by Mix et al. [2001]. 


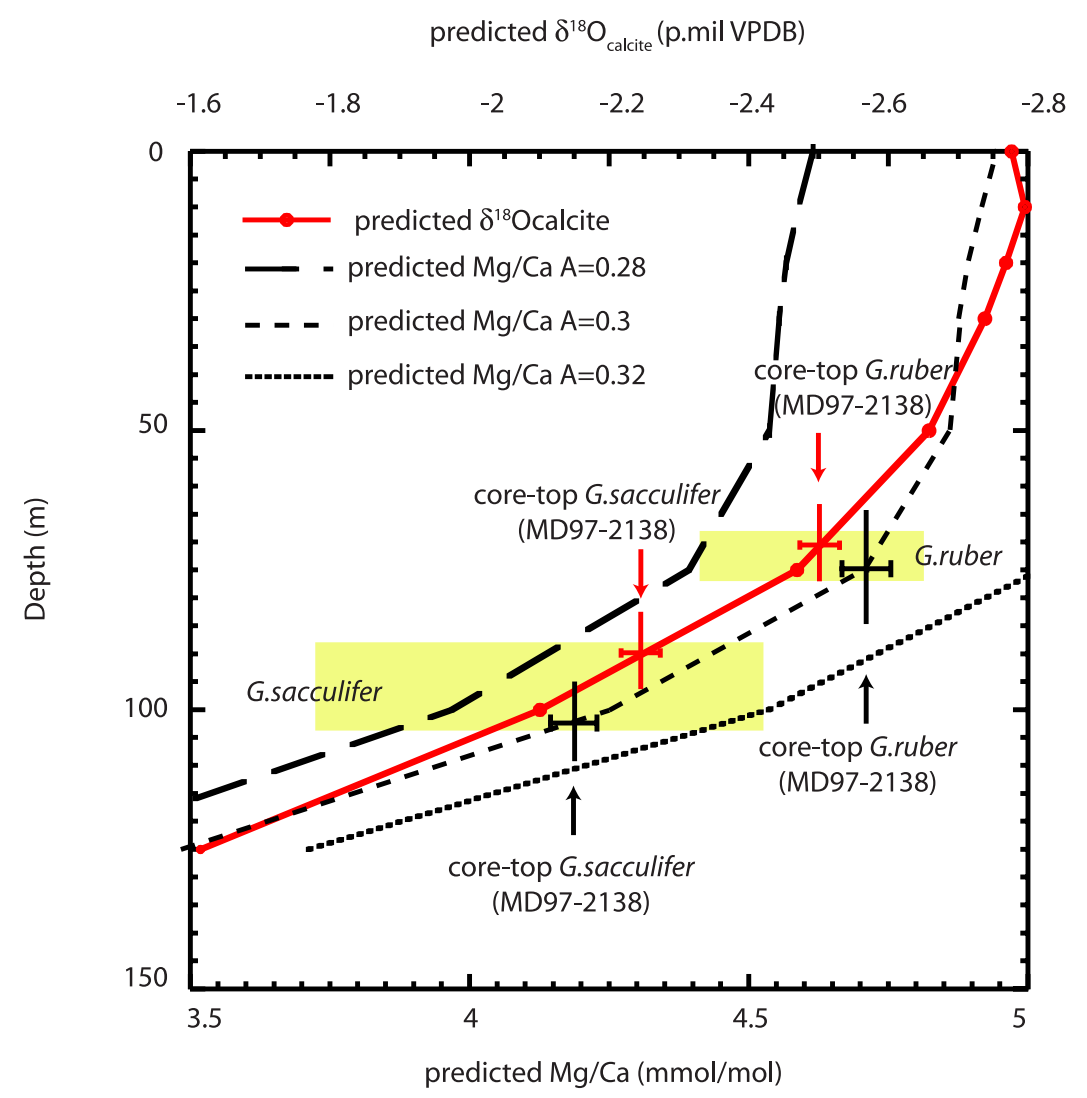

Figure 3. Predicted depth profiles of $\delta^{18} \mathrm{O}$ calcite (red line) and $\mathrm{Mg} / \mathrm{Ca}$ for three different preexponential constants ranging 0.28 to 0.32 (black lines) for the MD97-2138 site, using the modern annual temperature and salinities from the World Ocean Atlas. The red crosses indicate the observed $\delta^{18} \mathrm{O}$ core top values in MD97-2138, whereas the black crosses stand for the observed $\mathrm{Mg} / \mathrm{Ca}$ values in $G$. ruber and $G$. sacculifer. Crosses also display the analytical errors for both $\delta^{18} \mathrm{O}$ and $\mathrm{Mg} / \mathrm{Ca}$ measurements.

change substantially between the Late Holocene and now. We postulate that (1) the core top $\delta^{18} \mathrm{O}$ and $\mathrm{Mg} / \mathrm{Ca}$ should equally reproduce the vertical hydrographic structure with $G$. ruber living at shallower depth than $G$. sacculifer and (2) depth habitats inferred from the match between core top $\mathrm{Mg} / \mathrm{Ca}$ values and the predicted $\mathrm{Mg} / \mathrm{Ca}$ profile should be consistent with those inferred from the $\delta^{18} \mathrm{O}$ profile. We construct a set of predicted depth profiles of $\mathrm{Mg} / \mathrm{Ca}$ using a fixed exponential of 0.095 and a range of preexponential constants spanning 0.28 to 0.32 . A preexponential constant of 0.28 was used to reconstruct deglacial changes in the Sulu Sea core MD97-2141 [Rosenthal et al., 2003]. We also calculated the predicted $\delta^{18} \mathrm{O}_{\text {calcite }}$ profile. To calculate the latter profile, we first convert salinity values from the World Ocean Atlas [Conkright et al., 1998] into $\delta^{18} \mathrm{O}_{\mathrm{sw}}$ using the equation $\delta^{18} \mathrm{Osw}=-14.379+0.42264 *$ sea surface salinity (SSS), based on modern upper ocean measurements from the equatorial Pacific (within the $20^{\circ} \mathrm{N}-20^{\circ} \mathrm{S}$ latitudinal band and for depths ranging 0 to $200 \mathrm{~m}$ [Schmidt, 1999]). Then, the $\delta^{18} \mathrm{O}_{\text {calcite }}$ profile was computed using Bemis' equation linking $\delta^{18} \mathrm{O}_{\mathrm{sw}}$ and temperature as determined from low-light cultures of Orbulina universa [Bemis et al., 1998]. Both salinity and temperature for this calculation are annual means from the World Ocean Atlas [Conkright et al., 1998]. As shown in Figure 3, a preexponential value of 0.3 provides a suitable reconstruction in terms of consistency between measured core top foraminiferal $\delta^{18} \mathrm{O}$ and $\mathrm{Mg} / \mathrm{Ca}$ (based on the top most $10 \mathrm{~cm}$ in core MD97-2138) and predicted values from the modern hydrography. The inferred depth habitats, at the base of the mixed layer for $G$. ruber and below that for G. sacculifer, are generally consistent with the water column distribution of these species [Fairbanks et al., 1979]. Using the above equation, the core top $\mathrm{Mg} / \mathrm{Ca}$-based temperature estimate for $G$. ruber is $28.9^{\circ} \mathrm{C}$, whereas the estimated core top temperature from G. sacculifer is $27.7^{\circ} \mathrm{C}$, i.e., $\sim 1.2^{\circ} \mathrm{C}$ colder than the one measured on $G$. ruber, in agreement with their assumed depth habitats (Table 3 ).

[21] The temporal variability in $\delta^{18} \mathrm{O}$ and $\mathrm{Mg} / \mathrm{Ca}$ offsets between the two planktonic species suggests that the hydrography of the upper water column changed during the last deglaciation (Figure 2). The G. ruber $\mathrm{Mg} / \mathrm{Ca}-$ based SST record indicates a $3.0^{\circ} \pm 0.6^{\circ} \mathrm{C}$ change between the LGM and the Holocene, whereas the G. sacculifer temperature ranges about $2.3^{\circ} \pm 0.7^{\circ} \mathrm{C}$, thus suggesting that significant changes in surface and shallow subsurface temperatures might have occurred in the western equatorial Pacific during the last deglaciation, in accord with results 


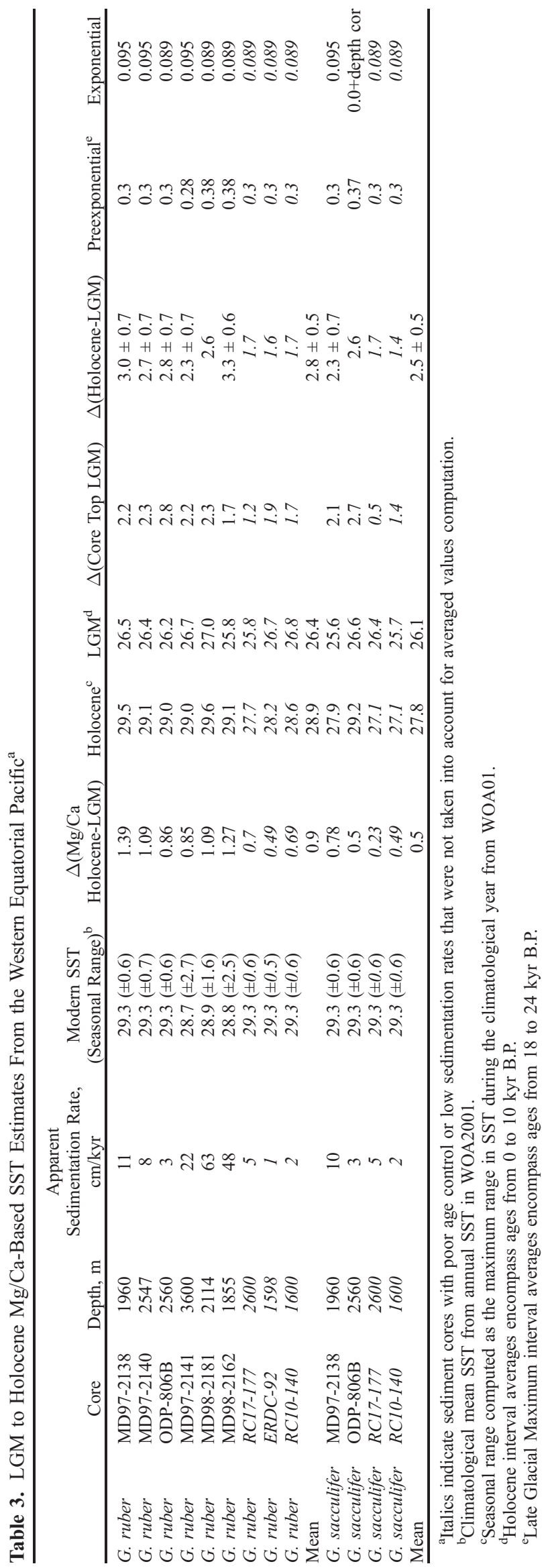

from the near by core of MD97-2140 [de Garidel-Thoron et al., 2005]. The G. ruber and G. sacculifer temperature records also point toward an early Holocene warm period in the western Pacific, although the timing of this event as recorded by the two species is not consistent. As the core is missing the late Holocene period, we cannot draw any firm conclusion on Holocene climate dynamics of the warm pool.

\subsection{Western Pacific Warm Pool SSTs Derived From CLIMAP Transfer Functions}

[22] Applying the Pacific transfer function (FP-12E) to faunal counts from MD97-2138 core we estimate summer SST of $28^{\circ} \mathrm{C}$ at the core top (Figure 2), which is cooler than modern mean summer temperature of $29.4^{\circ} \mathrm{C}$ [Conkright et al., 1998]. The reconstructed winter core top SST is $\sim 24.6^{\circ} \mathrm{C}$, i.e., $3.4^{\circ} \mathrm{C}$ lower than the summer estimates. In contrast, the modern seasonal range in WPWP is only $0.4^{\circ} \mathrm{C}$ [Conkright et al., 1998]. The summer equation predicts relatively stable SSTs, varying by less than $0.7^{\circ} \mathrm{C}$ SST through the past $30 \mathrm{kyr}$. In contrast, the winter equation suggests significant LGM to Holocene change of about $2.3^{\circ} \mathrm{C}$. Indeed, during the early Holocene, FP12-E winter estimates reach $25^{\circ} \mathrm{C}$ between 5 and $9 \mathrm{ka}$ as compared with about $23^{\circ} \mathrm{C}$ during the LGM, whereas the summer estimate reaches $28.1^{\circ} \mathrm{C}$ in the early Holocene from $27.5^{\circ} \mathrm{C}$ during the LGM. These transfer function results are consistent with a recent study of the WPWP that indicates a very low temperature variability during the last $38 \mathrm{kyr}$ based on the summer FP-12E equation, whereas estimates based on the winter equation suggest a larger glacial-interglacial amplitude of about $\sim 1^{\circ}-3^{\circ} \mathrm{C}$ [Chen et al., 2005a]. In summary, the summer equation predicts a reasonable mean WPWP SST during the late Holocene, but does not show signifcant glacial-interglacial change. In contrast, the winter SST equation predicts much cooler than modern core top SSTs but indicates a larger deglacial change than previously suggested from planktonic foraminifera transfer functions.

\subsection{Western Pacific Warm Pool SSTs Derived From Alkenones}

[23] $\mathrm{Uk}_{37}^{\prime}$ SSTs are calculated by means of the calibration of Sonzogni et al. [1997], which is based on low-latitude core tops from the Indian Ocean including samples representing SSTs between $24^{\circ}$ and $30^{\circ} \mathrm{C}$. This $\mathrm{Uk}_{37}^{\prime}$ versus SST linear equation has a reduced slope $\left(0.024 /{ }^{\circ} \mathrm{C}\right)$ when compared to the one $\left(0.033 /{ }^{\circ} \mathrm{C}\right)$ derived from the linear equation based on core tops compiled from all oceans [Muller et al., 1998]. The calibration by Sonzogni et al. has not been tested in the WPWP, but it seems to better estimate warm SST. Support for this choice comes from close inspection of the global compilation by Müller et al., suggesting that the relationship flattens out at high temperatures. In addition, culture studies of different strains of Gephyrocapsa oceanica and Emiliania huxleyi [Conte et al., 1998] and measurements of sinking particulate matter from Bermuda [Conte et al., 2001] strongly suggest that the real shape of the $\mathrm{Uk}_{37}^{\prime}$ vs. SST is probably sigmoidal, i.e., the $\mathrm{Uk}_{37}^{\prime}$ index converges asymptotically toward 0 and 1 , for low and high temperatures, respectively [Conte et al., 2006]. In Figure 2 we also provide SST estimates calculated with the linear 
equation by Prahl et al. [1988], which is based on culture of E. huxleyi, between $10^{\circ}$ and $25^{\circ} \mathrm{C}$, and thus might not be suitable for the high SST of the western equatorial Pacific, where the nannoflora is dominated mainly by gephyrocapsiids [Bentaleb et al., 2002]. The equation by Prahl et al. is generally used as the standard one and it is indistinguishable from the global core top calibration of Muller et al. [1998]. It is important, however, to note that the range of SSTs documented here falls within the upper boundary of all extant calibrations, where calibration data sets are scarce and analytical issues might also be critical [Pelejero and Calvo, 2003]. We estimate core top SSTs of $29.3^{\circ} \mathrm{C}$ and $28^{\circ} \mathrm{C}$ using the Sonzogni and Prahl equations, respectively (Figure 2c). Throughout the record, the estimates of Sonzogni are consistently $\sim 1^{\circ} \mathrm{C}$ higher than those of Prahl. At the core top, the estimates derived from the Sonzogni equation approximate the modern surface temperature $\left(29.4^{\circ} \mathrm{C}\right)$, whereas those based on the Prahl equation are consistent with the temperature at the base of the euphotic zone. LGM alkenone-based temperature estimates are $1.3^{\circ} \mathrm{C}$ cooler than during the Holocene. It is noteworthy, however, that the alkenone index is at saturation (i.e., $\mathrm{Uk}_{37}^{\prime}=1$ ) during the early Holocene and therefore the calculated $1.3^{\circ} \mathrm{C}$ amplitude is likely a minimum estimate for the LGM to Holocene warming.

\subsection{Western Pacific Hydrologic Changes Inferred From $\delta^{18} \mathbf{O}_{\text {sw }}$}

[24] $\mathrm{Mg} / \mathrm{Ca}$ temperature estimates are used to remove the thermal effect from the $\delta^{18} \mathrm{O}$ of calcite, in order to calculate the oxygen isotope composition of the water $\left(\delta^{18} \mathrm{O}_{\mathrm{sw}}\right)$. The $\delta^{18} \mathrm{O}_{\text {sw }}$ is computed using the Bemis Orbulina universa low-light equation [Bemis et al., 1998]. Furthermore, in order to unravel the local hydrology from the global ice volume isotopic effect on the oxygen isotope signal, we subtract the ice volume component from the calculated seawater $\delta^{18} \mathrm{O}$ record. This component is computed from an assumed linear relationship between sea level [Lambeck and Chappell, 2001] and the global $\delta^{18} \mathrm{O}$ record of Waelbroeck et al. [2002], though the ice volume to sea surface $\delta^{18} \mathrm{O}_{\mathrm{sw}}$ correlation might be more complex [Duplessy et al., 1991]. The LGM sea level decrease of $140 \mathrm{~m}$, which is associated with a global $1.05 \% \delta^{18} \mathrm{O}$ increase, constrains the slope of this correlation. On the basis of this first-order approximation, we estimate core top $\delta^{18} \mathrm{O}_{\mathrm{sw}}$ values of 0.5 and $0.4 \%$, and LGM ice volume-corrected values of -0.3 and $-0.1 \%$ for $G$. ruber and $G$. sacculifer, respectively. The basic feature of those $\delta^{18} \mathrm{O}_{\mathrm{sw}}$ records is that for both species, the $\delta^{18} \mathrm{O}_{\mathrm{sw}}$ was on average $0.3 \%$ lower between 15 and $30 \mathrm{ka}$ than during the Holocene.

[25] Some large fluctuations in $\delta^{18} \mathrm{O}_{\mathrm{sw}}$ are apparent within the LGM (from -0.4 to $+0.3 \%$ ). Whether these large oscillations are linked to real oceanographic changes, or result from the propagation of analytical and methodological errors in the different steps of this computation (G. A. Schmidt et al., Global seawater oxygen-18 database, 1999, available at http://data.giss.nasa.gov/o18data/), needs to be assessed but they do not alter the main finding of reduced seawater $\delta^{18} \mathrm{O}$ during the LGM. Note that assuming an overprint of dissolution on $\mathrm{Mg} / \mathrm{Ca}$ paleotemperatures (see below), LGM $\delta^{18} \mathrm{O}_{\text {sw }}$ values for the MD97-2138 core may account for $\sim 0.1$ and $0.3 \%$ for $G$. ruber and $G$. sacculifer, respectively.

\section{Discussion}

5.1. Assessment of Postdepositional Effects on $\mathrm{Mg} / \mathrm{Ca}-$ Derived SSTs

[26] Questions as to the possibility that postdepositional dissolution might have biased $\mathrm{Mg} / \mathrm{Ca}$-based SST estimates still linger. Evidence from core top studies demonstrate that planktonic foraminiferal $\mathrm{Mg} / \mathrm{Ca}$ is susceptible to postdepositional dissolution on the seafloor, with the degree of alteration increasing with water depth (or decreasing in the carbonate saturation state of the bottom water [Brown and Elderfield, 1996; Rosenthal et al., 2000]). Moreover, these studies and others [Schulte and Bard, 2003] suggest that dissolution of foraminiferal shells starts well above the lysocline, because of organic matter remineralization within the sediment.

[27] Available dissolution indices in core MD97-2138 suggest possibly more enhanced foraminiferal dissolution during the LGM than the early to mid-Holocene (Figure 2), which is likely driven by the increase of organic matter flux into the sediment during the glacial interval as suggested by higher total $\mathrm{C}_{37}$ alkenone concentrations. To date, methods suggested for correcting $\mathrm{Mg} / \mathrm{Ca}$-based SST estimates for dissolution effects are applicable only for surface sediments, but cannot be applied to correct down-core records [Dekens et al., 2002; Rosenthal and Lohmann, 2002]. Note, however, that the glacial values of all three dissolution indices (i.e., G. ruber shell weight, fragmentation index and \% coarse fraction) are not substantially different than at the core top. Therefore, although all three indices suggest an increase in dissolution between $7 \mathrm{ka}$ and the top, $\mathrm{Mg} / \mathrm{Ca}$ ratios initially increase and then stay stable. Thus we conclude that the latter reflect primarily a temperature signal. Nonetheless, below we try to evaluate the potential bias in our $\mathrm{Mg} / \mathrm{Ca}$ derived SSTs due to nontemperature related processes.

[28] First, we compare $\mathrm{Mg} / \mathrm{Ca}$ records from several western equatorial Pacific cores, characterized by different sedimentation rates, taken at different water depths and with different organic matter content. The comparison among $\mathrm{Mg} / \mathrm{Ca}$ records from this region shows differences in both absolute $\mathrm{Mg} / \mathrm{Ca}$ ratios and LGM-HL (Holocene) $\Delta \mathrm{Mg} / \mathrm{Ca}$ changes (Table 3). For example, the LGM-HL $\triangle \mathrm{Mg} / \mathrm{Ca}_{\text {G. ruber }}$ changes is about $1.2 \mathrm{mmol} / \mathrm{mol}$ in MD-97$2138(1900 \mathrm{~m}), 1.1 \mathrm{mmol} / \mathrm{mol}$ in MD97-2140 (2547 m) [de Garidel-Thoron et al., 2005], and $\sim 0.9 \mathrm{mmol} / \mathrm{mol}$ in ODP 806B site $(2520 \mathrm{~m})$ [Lea et al., 2000] (Figure 4 and Table 3). A smaller, but nonetheless significant, $\mathrm{Mg} / \mathrm{Ca}$ offset $(\sim 0.3 \mathrm{mmol} / \mathrm{mol})$ is observed for $G$. sacculifer records between MD97-2138 and the deeper ODP 806B cores (Figure 4). The differences in $\mathrm{Mg} / \mathrm{Ca}$ values between the cores are greater during the Holocene than during the glacial interval. As these three cores are located within the WPWP s.s., where both spatial and seasonal temperature changes are negligible, the differences cannot be attributed to variable oceanographic and climatic conditions (Table 1). Instead, offsets in $\mathrm{Mg} / \mathrm{Ca}$ might be due to one or a combination of the following factors: (1) variable dissolution effects on each record; (2) mixing of glacial and 


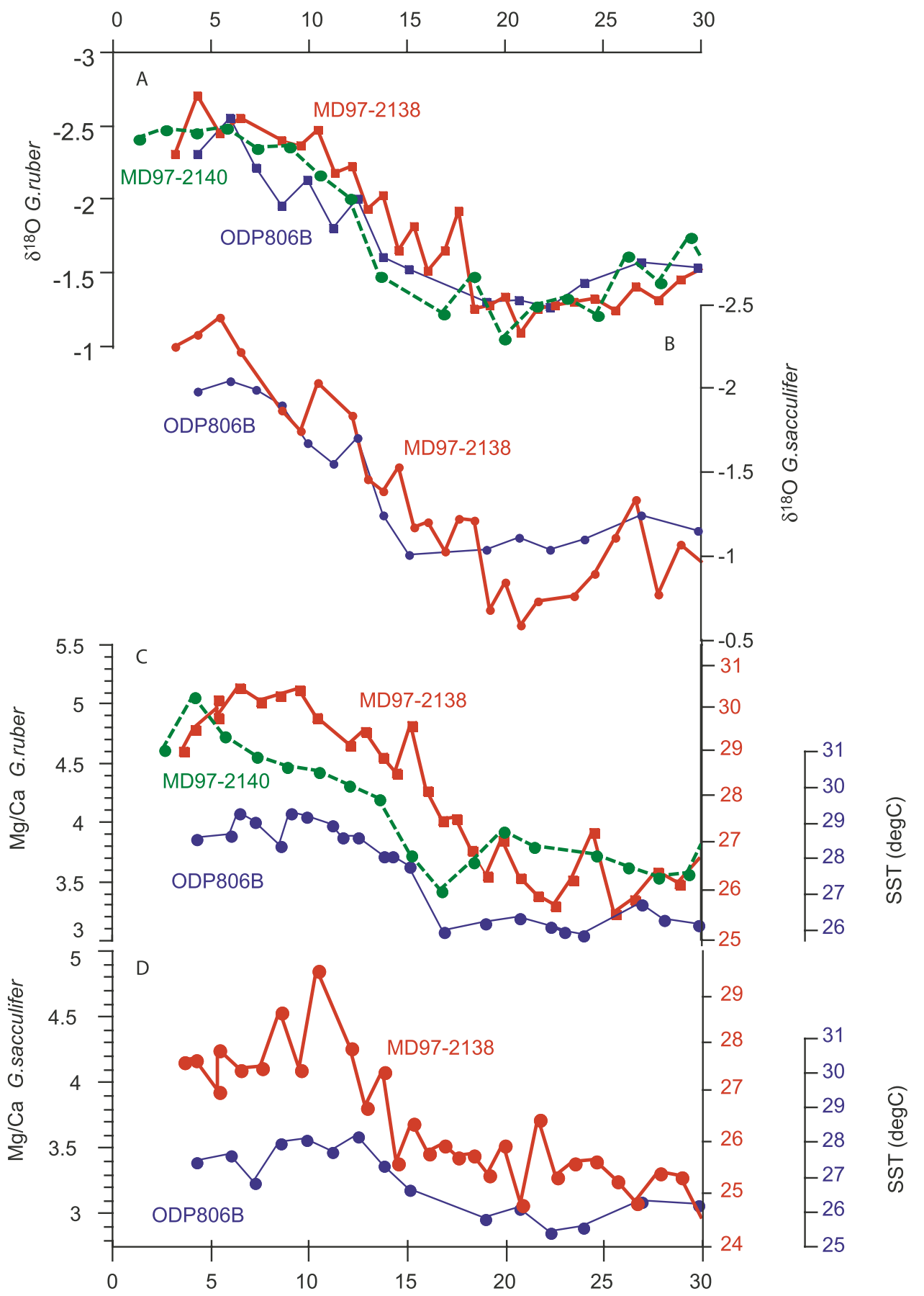

Figure 4. Oxygen isotopes, $\mathrm{Mg} / \mathrm{Ca}$, and $\mathrm{Mg} / \mathrm{Ca}$-based temperatures estimates from Western Pacific Warm Pool sediment cores MD97-2138 (red line), MD97-2140 (green line), and ODP 806B (blue line). The $\delta^{18} \mathrm{O}$ records for (a) G. ruber species and (b) G. sacculifer. The $\mathrm{Mg} / \mathrm{Ca}$ and $\mathrm{Mg} / \mathrm{Ca}-\mathrm{based} \mathrm{SST}$ in (c) G. ruber and (d) G. sacculifer. The two temperature scales correspond to the equation we used in this work (red scale), which applies to both MD sediment cores, and Lea et al. [2000] calibration (blue scale), which applies to ODP 806B core. See text for more details on the calibration used here.

interglacial sediments in low sedimentation rates cores; and (3) methodological differences among laboratories.

[29] ODP site 806B and MD97-2140 are about $600 \mathrm{~m}$ deeper than MD97-2138 and therefore likely to be affected to a greater extent by dissolution as suggested by core top calibrations. On average, $\mathrm{Mg} / \mathrm{Ca}_{G}$. ruber values at $\mathrm{MD} 97-$ 2138 are about $1 \mathrm{mmol} / \mathrm{mol}$ higher than those observed at ODP 806B, but similar to those obtained in MD97-2140, which comes from the same depth as ODP 806B. As all cores are located above the modern lysocline, the difference 


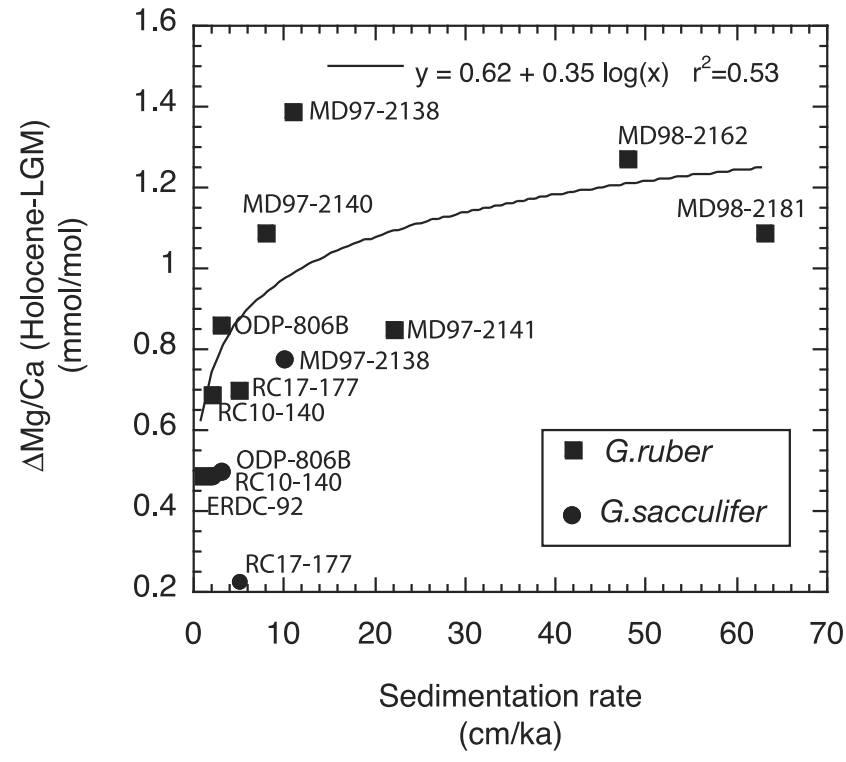

Figure 5. LGM to Holocene $\mathrm{Mg} / \mathrm{Ca}$ in planktonic foraminifera shell as a function of sedimentation rate (here computed as the average sedimentation rate between the end of the LGM and the core top). Note that cores with less than $\sim 8$ to $10 \mathrm{~cm} / \mathrm{kyr}$ sedimentation rate are marked by a dampening of the glacial to Holocene contrast, likely because of the effect of bioturbation.

in $\mathrm{Mg} / \mathrm{Ca}$ ratios suggests that dissolution effects among the cores are not strictly a function of depth but may also depend on other variables such as the organic carbon content of the sediment [Schulte and Bard, 2003]. Using a temperature sensitivity of $9.5 \%$ per ${ }^{\circ} \mathrm{C}$, the difference in $\Delta \mathrm{Mg} / \mathrm{Ca}_{\text {G. ruber }}$ estimates between MD97-2138 and MD972140 translate to $\sim 0.5^{\circ} \mathrm{C}$, whereas the difference in $\Delta \mathrm{Mg}$ / Ca between MD97-2138 and ODP 806B translates to $\sim 1^{\circ} \mathrm{C}$. The LGM-HL $\Delta \delta^{18} \mathrm{O}_{G \text {. ruber }}$ amplitude in MD97-2138, MD97-2140 and ODP 806B are about 1.16\%, 1.21\%o and $0.94 \%$, respectively. In other words, whereas the $\Delta \delta^{18} \mathrm{O}_{G}$. ruber in MD97-2138 and MD97-2140 are very similar, there is $\sim 0.22 \%$ difference in $\Delta \delta^{18} \mathrm{O}_{G}$. ruber between MD97-2138 and ODP 806B, which is consistent with the $\sim 1{ }^{\circ} \mathrm{C}$ difference in $\mathrm{Mg} / \mathrm{Ca}$-derived $\Delta \mathrm{SST}$ calculated above. As modern SSTs are the same at both sites, the comparison between $\mathrm{Mg} / \mathrm{Ca}$ and $\delta^{18} \mathrm{O}$ changes suggests that either both parameters are affected by dissolution to a similar extent, or that the difference in $\Delta \delta^{18} \mathrm{O}_{G}$. ruber between MD97-2138 and ODP 806B are not strictly due to the alteration of foraminifera shell composition by dissolution.

[30] The LGM-HL $\Delta \mathrm{Mg} / \mathrm{Ca}_{G}$. ruber amplitude in core MD-97-2138 is about $1.2 \mathrm{mmol} / \mathrm{mol}$, whereas the LGMHL $\Delta \mathrm{Mg} / \mathrm{Ca}_{G}$. sacc amplitude is $0.8 \mathrm{mmol} / \mathrm{mol}$. At face value, these amplitudes suggest LGM-HL temperature change of $3.0^{\circ} \mathrm{C}$ and $2.3^{\circ} \mathrm{C}$, based on G. ruber and G. sacculifer $\mathrm{Mg} /$ $\mathrm{Ca}$, respectively (Table 3 ). These values may combine, however, the effects of both increase in SST and possibly a decrease in dissolution intensity on foraminiferal $\mathrm{Mg} / \mathrm{Ca}$ during the deglaciation (which covary in this core).
[31] While we cannot exactly quantify the relative contribution of each of individual variable, we tentatively try to estimate an upper limit for the dissolution effect. Depth transects down the Ontong Java Plateau show a dissolution driven decrease of about 0.5 and $0.3 \mathrm{mmol} / \mathrm{mol}$ in $\mathrm{Mg} / \mathrm{Ca}$ ratios of G. ruber and G. sacculifer, respectively, for one kilometer increase in depth (between 1.6 and $2.6 \mathrm{~km}$ [Dekens et al., 2002]). As a sensitivity test, we consider the effect of decreasing the dissolution intensity at MD972138 during the deglaciation by the equivalent of a $1 \mathrm{~km}$ lysocline shoaling, the same as the difference in the modern lysocline depth between the Atlantic and Pacific oceans. Accounting for such hypothetical changes in dissolution intensity might reduce our estimate of LGM-HL temperature changes in core MD97-2138 to $1.9^{\circ} \mathrm{C}$ and $1.3^{\circ} \mathrm{C}$, based on G. ruber and G. sacculifer $\mathrm{Mg} / \mathrm{Ca}$, respectively.

[32] Bioturbation may have a significant impact on the glacial-Holocene $\mathrm{Mg} / \mathrm{Ca}$ amplitude at sites with low sedimentation rates (Figure 5 from Table 3 data). In Figure 5 we show that there is a significant logarithmic relationship between sedimentation rate and the glacial-interglacial $\Delta \mathrm{Mg} / \mathrm{Ca}$ amplitude. At low sedimentation rates it is likely that glacial foraminifera are mixed with interglacial ones, thus reducing the apparent $\Delta \delta^{18} \mathrm{O}$ and $\Delta \mathrm{Mg} / \mathrm{Ca}$ LGM-HL changes based on analysis of multiple shells in each sample [Anderson et al., 1989; Broecker and Peng, 1982]. At sedimentation rate $>8 \mathrm{~cm} / \mathrm{kyr}$, the $\Delta \mathrm{Mg} / \mathrm{Ca}$ (HL-LGM) stabilize at values of $1.1-1.3 \mathrm{mmol} / \mathrm{mol}$. The dependence on sedimentation rates, though not surprising, explains the difference between MD97-2140 and ODP 806B, which come from the same water depth but have very different sedimentation rates (Tables 1 and 3); the low sedimentation rate at the latter core $(3 \mathrm{~cm} / \mathrm{kyr})$ also explains the relatively low $\Delta \delta^{18} \mathrm{O}_{G \text {. ruber }}$ and $\Delta \mathrm{Mg} / \mathrm{Ca} \mathrm{a}_{G \text {. ruber }}$ amplitudes.

\section{2. $\mathrm{Mg} / \mathrm{Ca}$-Derived Temperature Changes in the Western Equatorial Pacific}

[33] The calculated temperature amplitude of the G. ruber record from core MD97-2138 (uncorrected for dissolution effects) suggests $3.0^{\circ} \pm 0.7^{\circ} \mathrm{C}$ warming during the last deglaciation (Figure 2c and Table 3). This deglacial change is higher than, but within the range of that obtained from other WPWP G. ruber records including ODP 806B site $\left(2.8^{\circ} \pm 0.7^{\circ} \mathrm{C}[\right.$ Lea et al., 2000$\left.]\right)$, and MD97-2140 site $\left(2.7^{\circ} \pm\right.$ $0.5^{\circ} \mathrm{C}$ [de Garidel-Thoron et al., 2005]). These results contrast, however, with those obtained from lower sedimentation rate cores, which display a lower glacial to Holocene temperature change of $\sim 1.7^{\circ} \mathrm{C}$ (RC17-177 site, $1.7^{\circ} \mathrm{C}$; ERDC92, $1.6^{\circ} \mathrm{C}$; and $\mathrm{RC} 10-140,1.7^{\circ} \mathrm{C}$; see Table 3 for references). For G. sacculifer the amplitude of $2.3^{\circ} \mathrm{C}$ LGM to Holocene warming in MD97-2138 is comparable with $\sim 2.1^{\circ} \mathrm{C}$ seen in ODP $806 \mathrm{~B}$ [Dekens et al., 2002]. Note that for this synthesis, we use the original equations of quoted studies.

[34] Differences in cleaning methods among laboratories are considered here to have a minimal impact on $\mathrm{Mg} / \mathrm{Ca}$ derived temperatures. Although offsets due to dissolution and methodological differences may cause $>10 \%$ variability among cores, differences in SST estimates are significantly 
Table 4. LGM to Holocene Alkenone and Foraminiferal Transfer Functions, SST Estimates, and Thermocline Depth Estimate From the Western Equatorial Pacific

\begin{tabular}{|c|c|c|c|c|c|c|c|}
\hline & Core & $\begin{array}{c}\text { Climatological } \\
\text { Modern SST and } \\
\text { Thermocline Depth } \\
\left( \pm \text { Seasonal Range) }{ }^{\mathrm{a}, \mathrm{b}}\right.\end{array}$ & Holocene $^{c}$ & $\mathrm{LGM}^{\mathrm{d}}$ & $\Delta$ (CoreTop-LGM) & $\Delta($ Holocene-LGM $)$ & Reference \\
\hline Alkenone $\mathrm{T}$ & MD97-2138 & $29.3( \pm 0.6)$ & 29.2 & 27.9 & 1.4 & 1.3 & this study \\
\hline Alkenone $\mathrm{T}$ & KH92-1-5cBX & $29.3( \pm 0.8)$ & 28 & 27 & 1.5 & 1 & Ohkouchi et al. [1994] \\
\hline WinterFP12E T & MD97-2138 & $29.3( \pm 0.6)$ & 24.9 & 23.7 & 1.1 & $1.2 \pm 0.6$ & this study \\
\hline SummerFP12E T & MD97-2138 & $29.3( \pm 0.6)$ & 28.0 & 27.7 & 0.3 & $0.3 \pm 0.6$ & this study \\
\hline $\begin{array}{l}\text { Thermocline } \\
\text { depth, m }\end{array}$ & MD97-2138 & -154.0 & -152.6 & -151.4 & -57.6 & $-1.1 \pm 24$ & this study \\
\hline
\end{tabular}

${ }^{\mathrm{a}}$ Climatological mean temperature and thermocline depth from annual temperatures in WOA2001.

${ }^{\mathrm{b}}$ Seasonal range computed as the maximum range in SST during the climatological year from WOA01.

${ }^{\mathrm{c}}$ Holocene interval averages encompass ages from 0 to $10 \mathrm{kyr}$ B.P.

${ }^{\mathrm{d}}$ Late Glacial Maximum interval averages encompass ages from 18 to 24 kyr B.P.

smaller, as they are compensated for by the use of regional, or dissolution-corrected calibrations [Rosenthal et al., 2004]. Here we compare the results of Lea et al. [2000], who used a "full" cleaning protocol, whereas the "short" protocol (which does not include a reductive step) [Barker et al., 2003] was used in MD97-2138 and MD97-2140 cores. Because Lea et al. [2000] used a specific regional calibration for their Pacific record, with lower temperature sensitivity than used here $\left(8.9 \%\right.$ per ${ }^{\circ} \mathrm{C}$ rather than the $9.5 \%$ per ${ }^{\circ} \mathrm{C}$ ), their estimated LGM-HL $\Delta \mathrm{SST}$ is consistent with our estimates from MD97-2138.

[35] In summary, $\mathrm{Mg} / \mathrm{Ca}_{G \text {. ruber }}$ ratios from high sedimentation rate records $(>8 \mathrm{~cm} / \mathrm{ky})$ indicate that glacial surface temperatures in the WPWP were on average $2.9^{\circ} \pm 0.5^{\circ} \mathrm{C}$ cooler than at present; $\mathrm{Mg} / \mathrm{Ca}_{G}$. sacculifer ratios suggest smaller LGM cooling, of about $2.5^{\circ} \pm 0.5^{\circ} \mathrm{C}$ (Table 3). Accounting for possibly higher foraminiferal shell dissolution in these cores during the glacial interval would, at most, reduce these estimates to $1.9^{\circ} \mathrm{C}$ for $G$. ruber and $1.3^{\circ} \mathrm{C}$ for G. sacculifer, which are in the same range as changes of $\sim 2.3^{\circ} \mathrm{C}$ based on foraminiferal transfer functions calibrated for winter temperatures and $>1.3^{\circ} \mathrm{C}$ based on alkenones. Considering all these effects, we propose surface water temperature at the WPWP was about $2.5 \pm 0.7^{\circ} \mathrm{C}$ cooler during the LGM than at present (based on $\mathrm{Mg} / \mathrm{Ca}_{G}$, ruber $)$, whereas the subsurface temperature cooled by $1.8 \pm 0.7^{\circ} \mathrm{C}$ (based on $\mathrm{Mg} / \mathrm{Ca}_{G \text {. sacculifer }}$ ). In both cases the pooled errors (computed as the standard deviation) reflect the combined effects of analytical errors, variable dissolution effects, sedimentation rates and methodological differences. These errors do not include the external scatter linked to the calibration, which has been suggested to reach $\pm 1.2^{\circ} \mathrm{C}$ in a sediment trap study from the Atlantic Ocean [Anand et al., 2003].

\subsection{A Multiproxy Comparison of WPWP SSTs During the LGM}

[36] On the basis of the $\mathrm{Mg} / \mathrm{Ca}$ record of the planktonic foraminifer G. ruber from ODP site 806B, Lea et al. [2000] suggested that SSTs in the WPWP were $2.8^{\circ} \pm 0.7^{\circ} \mathrm{C}$ colder during the LGM than at present, an estimate larger than (but within the statistical uncertainty of) the $1^{\circ} \pm 2^{\circ} \mathrm{C}$ cooling proposed by CLIMAP [CLIMAP, 1981]. Estimates of similar magnitude, inferred from additional western equatorial Pacific $\mathrm{Mg} / \mathrm{Ca}$-based SST records, from the Sulu Sea
[Rosenthal et al., 2003], Mindanao Sea [Stott et al., 2002] and southern Makassar Strait (Indonesia) [Visser et al., 2003], support this first observation, thus lending more confidence to the argument that CLIMAP might have underestimated the degree of glacial cooling in the WPWP. It is unclear, however, whether the low estimates of glacial cooling generated by CLIMAP are due to stratigraphic uncertainties, the use of low sedimentation rate cores, or some inherent limitations of the transfer function method. Updated analyses of LGM temperatures based on fauna and using several statistical approaches confirm low-temperature changes throughout the region based on these methods, and suggest movement of the WPWP toward the east [Barrows and Juggins, 2005]. Mix et al. [1999] and Morey et al. [2005] note the relatively low sensitivity of faunal changes to temperature at warm sites such as the WPWP, thus indicating that changes inferred here from transfer functions must be considered lower limits.

[37] Comparing $\mathrm{Mg} / \mathrm{Ca}$-based with other SST proxy estimates from the WPWP has not been straightforward as the records come from different cores. Thus questions about stratigraphic matching and differences in sedimentation rates add uncertainty to the argument about the reliability of each of the different proxy records. For example, none of the 10 western equatorial Pacific cores used in the CLIMAP study was radiocarbon dated [Moore et al., 1980b]. Instead, the chronology of half of the 10 cores is based on oxygen isotope stratigraphy, whereas the chronology of the other five is based on biostratigraphic and lithologic correlations. These relative dating methods are, however, potentially associated with large uncertainties. This is clearly seen in the oxygen isotope record from MD97-2138, where the LGM interval cannot unequivocally be distinguished from the coldest maximum around $\sim 17 \mathrm{ka}$. The availability of SST estimates derived from $\mathrm{Mg} / \mathrm{Ca}$, alkenone and foraminiferal transfer functions in MD97-2138 removes these uncertainties and allows, for the first time, to evaluate the consistency among these proxy records in a single core from the WPWP. Using the winter FP-12E equation, we obtain that LGM SSTs were about $\sim 2^{\circ} \mathrm{C}$ colder than at present (Table 4 ). Whereas the amplitude of the glacial cooling is consistent with our low $\mathrm{Mg} / \mathrm{Ca}$-derived SST estimates from G. ruber, the absolute temperatures are lower by as much as $4^{\circ} \mathrm{C}$ relative to the $\mathrm{Mg} / \mathrm{Ca}$-derived SST record. Our faunal SST 
estimate is, however, within the range of other faunal estimates from this area [Chen et al., 2005a; CLIMAP, 1981].

[38] Our alkenone record is consistent with the faunalbased SST record, both in terms of relative changes and timing, although the absolute temperatures are significantly higher, and thus more similar with the $\mathrm{Mg} / \mathrm{Ca}-\mathrm{SST}$ record. The MD97-2138 alkenone record suggests Holocene-LGM $\triangle$ SST changes of $\sim 1^{\circ} \mathrm{C}$ (Table 4 ), which is consistent with another alkenone record from a box core in the WPWP [Ohkouchi et al., 1994]. As the latter record comes from a very low sedimentation rate core, the consistency between the two records suggests that bioturbation of glacial and interglacial sediments cannot explain the low alkenone-based $\triangle \mathrm{SST}$ estimates relative to those obtained from $\mathrm{Mg} / \mathrm{Ca}$ records. The alkenone-based glacial cooling is significantly lower than our minimum estimated cooling from $G$. ruber $\left(1.9^{\circ} \mathrm{C}\right)$, but consistent with the temperature change estimated from $\mathrm{Mg} / \mathrm{Ca}$ in $\mathrm{G}$. sacculifer. This suggests that alkenonereconstructed temperatures might be more representative of subsurface temperatures, as is also $\mathrm{Mg} / \mathrm{Ca}_{\text {G.sacculifer }}$. This hypothesis, though speculative, is supported by modern ecological observations of nannoflora from the warm pool. Indeed, one of the main alkenone producing species, E. huxleyii, does not live in the upper photic zone in the warm pool, but at a depth greater than $50 \mathrm{~m}$ below the sea surface [Hagino et al., 2000], in agreement with this hypothesis. Alternatively, alkenones and transfer functions might underestimate the LGM-HL amplitude because of calibration uncertainties in the upper limit of the calibration range. These uncertainties are linked for both the alkenones and FP12E transfer functions to the number of calibration samples within the $>29^{\circ} \mathrm{C}$ temperature range [Moore et al., 1980a; Pelejero and Calvo, 2003]. The latter corollary is consistent with the findings of low glacial-interglacial alkenone-based amplitude from a mid-Pleistocene record at ODP site 806 [McClymont and Rosell-Mele, 2005].

[39] The $2.5^{\circ} \pm 0.7^{\circ} \mathrm{C}$ WPWP cooling inferred from the $\mathrm{Mg} / \mathrm{Ca}$ records in the WPWP (Figure 5) is apparently consistent with continental temperature records. Indeed, western Pacific surrounding Equilibrium Lines Altitudes (ELA-snow lines) were depressed by more than $900 \mathrm{~m}$ $( \pm 135 \mathrm{~m})$ in the New Guinea island [Porter, 2001]. Modeling studies indicate that this $\triangle \mathrm{ELA}$ corresponds to a continental cooling of about $6^{\circ} \mathrm{C}$ to $3.5^{\circ} \mathrm{C}$ (accounting for sea level correction, increase in the lapse rate and precipitation changes) as reviewed by Porter [2001] and Prentice et al. [2005]. Note, however, that Hostetler and Clark [2000] and Prentice et al. [2005] point out that the chronologies on glacier advances here are poorly constrainted, and not necessarily linked to the global LGM. In summary, both marine $\mathrm{Mg} / \mathrm{Ca}$ and continental records thus converge toward an $\sim 2.5^{\circ} \pm 1{ }^{\circ} \mathrm{C}$ cooling over the ocean during the LGM. Our study also suggests that temperature estimates based on alkenones, faunal transfer function and $\mathrm{Mg} / \mathrm{Ca}$ G. sacculifer might represent changes in subsurface water and therefore underestimate the change in SSTs.

\subsection{Inferring Regional Hydrology From $\delta^{18} \mathrm{O}_{\text {sw }}$}

[40] Our new $\delta^{18}$ Osw records shed some new light on deglacial hydrological changes in the equatorial Pacific. At face value, the estimates (uncorrected for dissolution) are in agreement with other studies, which show negative shifts in surface water $\delta^{18} \mathrm{O}$ in the WPWP during the LGM compared with the Holocene (sites MD97-2140 and ODP 806 with $\Delta \delta^{18} \mathrm{O}_{s w}$ G. ruber of $-0.4 \%$ and $-0.4 \%$, respectively) (see Table 5 for references). On the basis of available data, it seems that the negative $\delta^{18} \mathrm{O}_{s w}$ shifts might have been restricted to the WPWP s.s. and did not extend westward. Moreover, it is unlikely that the geographical pattern of $\delta^{18} \mathrm{O}_{s w}$ is the result of the glacial-interglacial dampening of the ice volume $\delta^{18} \mathrm{O}$ amplitude in low sedimentation rate cores. Assuming that bioturbation reduced the glacial-interglacial $\delta^{18} \mathrm{O}_{s w}$ ice volume effect by $0.2 \%$, the lower sedimentation rates cores still indicate that fresher conditions might have prevailed in the eastern WPWP. The $G$. ruber record from the Mindanao Sea indicates that during the LGM surface water $\delta^{18} \mathrm{O}_{s w}$ was about $0.3 \%$ higher than at present [Stott et al., 2002]. Likewise, glacial surface water in the Makassar straits was about $0.1 \%$ o higher than at present [Visser et al., 2003]. The apparent regional differences in $\delta^{18} \mathrm{O}_{s w}$ attests to different controls on surface hydrography in both regions, which is not inconsistent with modern climatology; today the WPWP is strictly under the influence of the ENSO system, whereas the western sites are more under the influence of the east Asian monsoon system. Though, both systems are climatically linked, their signatures on the modern hydrography in these sites is very different and might explain the Sulu Sea anomaly, where the amplitude of $\delta^{18} \mathrm{O}_{\mathrm{sw}}\left(\Delta \delta^{18} \mathrm{O}_{s w}\right.$ G. rubber $=-0.3 \%$ in MD97-2141 core) is close to the one observed in the heart of the WPWP.

[41] Away from the equator, modern surface water $\delta^{18} \mathrm{O}$ and salinity are strongly and positively correlated [e.g., Craig et al., 1982]. Assuming similar relationships in the past, inferences about past changes surface salinity may be made from downcore $\delta^{18} \mathrm{O}_{s w}$ records. The $\Delta \delta^{18} \mathrm{O}_{s w}-\Delta \mathrm{SSS}$ relationship is not as strong in the tropics [Fairbanks et al., 1997]. At face value, estimates of $\delta^{18} \mathrm{O}_{s w}$ may suggest that during the LGM surface salinity decreased in the WPWP (near the sites of MD97-2138, MD97-2140 and ODP 806) and increased in the western sites of Mindanao and Makassar. We cannot rule out that the precipitation amount effect on the stable isotopes fractionation due to an increase in the convection might have also changed significantly the precipitation $/ \delta^{18} \mathrm{O}$ relationship through time within the WPWP [Dansgaard, 1964]. Nonetheless, the regional consistency among all the records from the heart of the WPWP suggests that the observed LGM decrease in $\delta^{18} \mathrm{O}_{\mathrm{sw}}$, was most probably a result of increased precipitation. Interpreting the $\delta^{18} \mathrm{O}_{\mathrm{sw}}$ records of the western equatorial marginal sites, such as those located in the Makassar straits and Mindanao basin, is even more complicated, as the oxygen isotopic signal of the precipitation depends on whether the precipitation comes primarily from marine or continental source [Hoffmann and Heimann, 1997]. The relationship between the two sources depends on the intensity ratio between the summer and winter east Asian monsoons. Thus, while the opposite pattern (toward decrease in precipitation) observed in the westernmost sites of the WPWP might reflect changes in surface salinity, we cannot rule out that it may also result 
from changes in the isotopic composition of the precipitation that are related to changes in the intensity of the east Asian summer monsoon during the last deglaciation [Wang et al., 2001]. Finally, the early to mid-Holocene period is characterized by an increase in $\delta^{18} \mathrm{O}_{\mathrm{sw}}$ at the MD97-2138 site, suggesting that the sea surface salinity increased during the early to mid-Holocene. This finding is consistent with mid-Holocene WPWP coral estimates of salinity changes [Gagan et al., 1998], and evidence for a long-term freshening of the equatorial Pacific surface ocean during the Holocene [Stott et al., 2004].

\subsection{Is ENSO-Like Analogy Consistent With Deglacial Changes in the WPWP?}

[42] Here we examine the changes in two major hydrographic properties associated with ENSO in the WPWP: (1) change in precipitation pattern and (2) change in the western equatorial Pacific thermocline depth. The examination suggests that an ENSO-like analogy may not be applicable for the last deglaciation.

[43] The $\delta^{18} \mathrm{O}_{\mathrm{sw}}$ records suggest a slight freshening of surface waters in the WPWP during cooler intervals. This observation is at odds with the modern El Niño pattern in which the western part of the warm pool (i.e., sites MD972138 and MD97-2140) is marked by higher salinities because of reduced precipitation, whereas the eastward part of the WPWP (e.g., site ODP 806B) is characterized by lower salinities associated with the eastward migration of the convection cell. Thus the broad regional freshening of the WPWP is consistent with a change in the mean state of the WPWP hydrologic cycle. On the basis of $\delta^{18} \mathrm{O}_{\mathrm{sw}}$ record from the Sulu Sea (MD97-2141) it was argued that the freshening might have resulted from a southward migration of the Intertropical Convergence Zone (ITCZ) during the LGM, rather than from El Niño-like conditions [Rosenthal et al., 2003]. The three cores discussed here are, however, very close to the equator, and therefore should not be affected, to a large extent, by ITCZ displacements. This hypothesis, though not impossible, is very unlikely to have contributed significantly to the freshening of the WPWP on orbital timescales. Thus neither seasonal (i.e., migration of the ITCZ) nor interrannual (i.e., ENSO like) analogies of modern climate variability can accurately account for past changes in western equatorial Pacific surface hydrography.

[44] Last, we examine the third diagnostic parameter of the equatorial Pacific mean state, that is the thermocline depth as reconstructed from planktonic foraminifera in the MD972138 core (Figure 6d). The thermocline depth record appears to match reasonably well with a primary production record estimated from coccolithophores from the same core [Beaufort et al., 2001], with increased primary production associated with deepening of the western equatorial Pacific thermocline during the deglaciation. These observations suggest an increase in the trade winds during the termination, which leads to an increase of primary production, and a deepening of the thermocline in the western Pacific, in a pattern more consistent with La Niña than El Niño conditions. This interpretation is also consistent with $p \mathrm{CO}_{2}$ reconstructions from Ontong-Java plateau, which point toward a La Niña like pattern during the last termination 


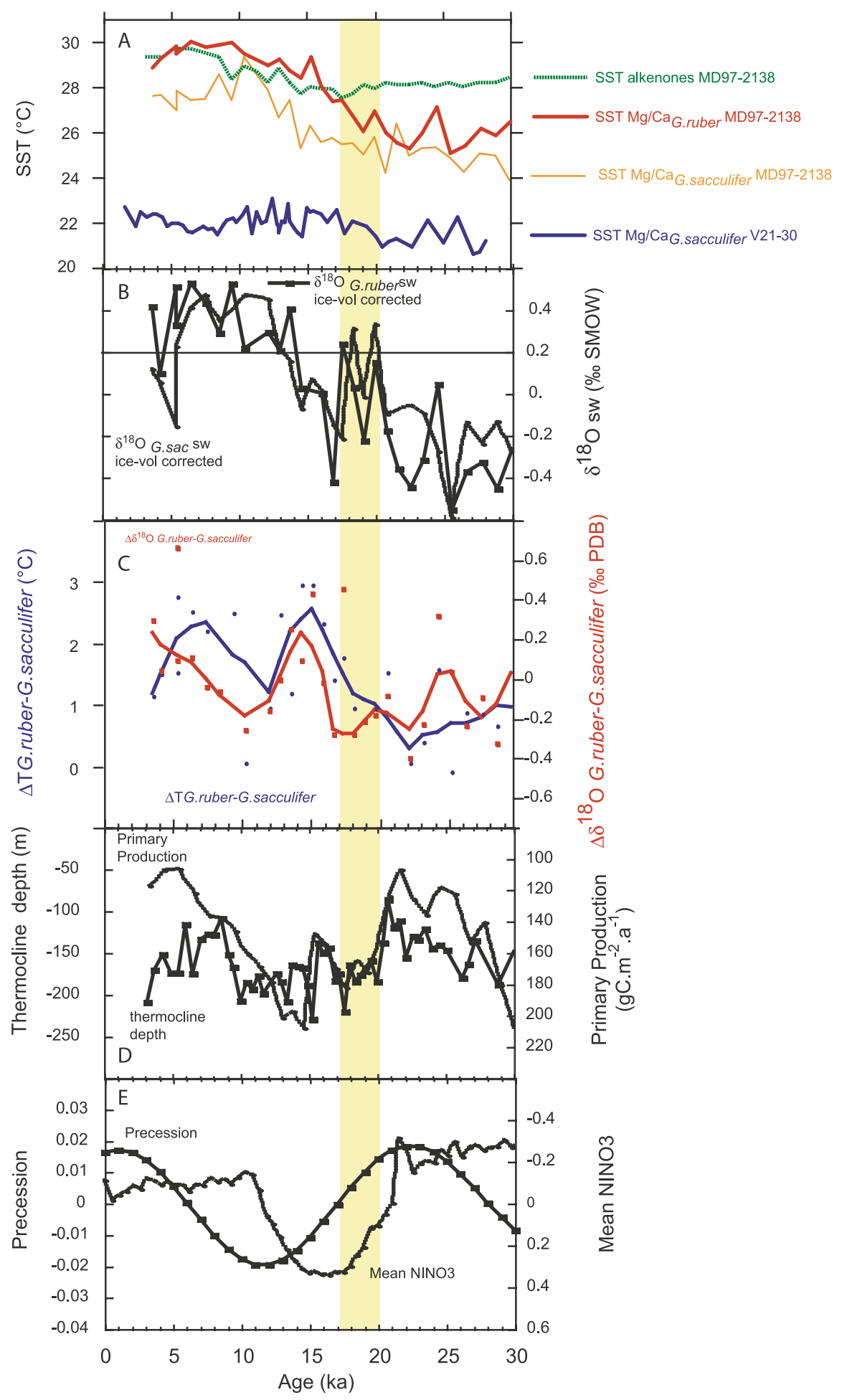

Figure 6. Comparison of proxy records which are diagnostic of modern ENSO state of the equatorial Pacific. (a) Comparison of MD97-2138 western Pacific temperature records derived from different proxies with a temperature record (V21-30) from the eastern Pacific cold tongue [Koutavas et al., 2002]. (b) The $\delta^{18} \mathrm{O}_{\mathrm{sw}}$ ice-corrected record for G. ruber and G. sacculifer in MD97-2138 core. (c) Difference in MD97-2138 G. ruber minus G. sacculifer temperatures (blue line) and $\delta^{18} \mathrm{O}_{\mathrm{sw}}$ (red line). The raw data were smoothed using a moving average window ranging 5 points. (d) MD97-2138 Primary production inferred from coccolithophorid assemblages and thermocline depth reconstruction based on foraminiferal transfer function (bold line). (e) Precession and mean NINO3 time series as derived by Clement and Cane model [Clement et al., 1999]. The shaded area corresponds to the 17-20 kyr B.P. interval. 
[Palmer and Pearson, 2003]. Such a mechanism has been attributed to precessional forcing of the mean equatorial state as modelled by a simple coupled ocean-atmosphere forced by orbital parameters [Clement et al., 1999] (Figure 6e).

[45] The pattern of deglacial change in primary production and thermocline depth (Figure 6d) contrasts with the primary production reconstruction which can be inferred from the total $\mathrm{C}_{37}$ concentration record in MD97-2138 (Figure 2e). Higher concentration in total $\mathrm{C}_{37}$ during the early last glacial period compared with the Holocene, suggests a significant decrease in primary production during the last deglaciation in the western Pacific. This pattern is supported by the large increase during the LGM of the content and accumulation rate of total organic matter measured in the nearby core MD97-2140 [Thevenon et al., 2004]. The apparent discrepancy between the organic proxies, the nannoflora indicator of primary production and foraminiferal tranfer function for thermocline depth, is problematic and will be explored in subsequent studies. Increased dissolution of the carbonates during the last glacial stage might have altered the accuracy of these geochemical, faunal and floral proxies. In summary, despite major changes occuring during the termination, no significant change in the western Pacific warm pool thermocline depth between the LGM and the Holocene is observed in the MD98-2138 record. This result confirms the lack of substantial evidence for an El Niño-like state of the equatorial Pacific during the LGM.

\section{Conclusions}

[46] Using a multiproxy approach, we show that LGM surface temperatures of the western equatorial Pacific as inferred from $\mathrm{Mg} / \mathrm{Ca}$ in the surface dwelling planktonic foraminifer, G. ruber, were about $2.5^{\circ} \pm 0.7^{\circ} \mathrm{C}$ cooler than during the Holocene. On the other hand, temperature estimates based on $\mathrm{Mg} / \mathrm{Ca}$ in G. sacculifer, alkenones and planktonic foraminifera faunal transfer functions converge toward lower glacial-interglacial amplitude within the range of $1.8^{\circ} \pm 0.7^{\circ} \mathrm{C}$ estimated from $\mathrm{Mg} / \mathrm{Ca}_{G \text {.sacculifer }}$. The smaller cooling inferred from the later proxies is presumably reflective of subsurface temperature rather than strict SSTs, though some uncertainties on the vertical distribution of the foraminifera remain. These estimates of LGM-
Holocene SST changes account for potential biases of foraminiferal $\mathrm{Mg} / \mathrm{Ca}$ due to variations in dissolution intensity and variable sedimentation rates among the different WPWP cores. Often, WPWP records showing a minimal glacialinterglacial surface cooling, as inferred from $\mathrm{Mg} / \mathrm{Ca}$ in G. ruber, come from low sedimentation rates cores $(<8 \mathrm{~cm} /$ kyr). Though bioturbation of glacial and interglacial sediments clearly contribute to smaller estimates of deglacial temperature changes in low sedimentation rates areas, the role of postdepositional dissolution on $\mathrm{Mg} / \mathrm{Ca}$ temperature estimates in high sedimentation rate cores needs further work to be clearly assessed. At the site of MD97-2138, increased supralysoclinal dissolution during the LGM is documented by increased fragmentation of planktonic foraminifera shells, likely driven by higher organic input (as documented by $\mathrm{C} 37$ concentration). Whereas the accurate impact of the supralysoclinal dissolution on glacialinterglacial amplitude cannot be resolved without a quantitative estimate of dissolution, we estimate that its maximum bias on the HL-LGM Mg/Ca-temperature estimate from this core was less than $1.5^{\circ} \mathrm{C}$ for G. ruber and $1{ }^{\circ} \mathrm{C}$ for G. sacculifer.

[47] The $\delta^{18} \mathrm{O}_{\mathrm{sw}}$ reconstructions indicate a surface freshening of most the WPWP during the LGM except for the westernmost marginal seas. The thermocline depth did not change significantly between the LGM and the Holocene period, although a strong deepening of the thermocline occurred during the deglaciation.

[48] On the basis of $\mathrm{Mg} / \mathrm{Ca}$-based temperatures, $\delta^{18} \mathrm{O}_{\mathrm{sw}^{-}}$ inferred salinity changes and planktonic foraminifera thermocline-depth reconstructions, we argue that the WPWP hydrography changes during the LGM cannot be described simply in terms of ENSO analogies.

[49] Acknowledgments. We thank Edith Vincent for her help with foraminifera taxonomy and ecology, S. Perron-Cashman and P. Field for help with the ICP-MS analyses, N. Buchet for foraminiferal picking, and D. Andreasen and C. Levi for discussions. The support of French MENRT, TAAF, CNRS/INSU, and IPEV to the Marion Dufresne and the IMAGES Program was necessary to retrieve the Calypso core. Financial support from CNRS/INSU, ECLIPSE, and ANR grants (T.deG.-T. and L.B.) and NSF grant OCE02-20922 (Y.R.) is acknowledged. E.B. acknowledges grants from the CNRS, the ANR, the Gary Comer Science and Education Foundation, and the European Community (project STOPFEN, HPRNCT-2002-0221).

\section{References}

Anand, P., H. Elderfield, and M. H. Conte (2003), Calibration of $\mathrm{Mg} / \mathrm{Ca}$ thermometry in planktonic foraminifera from a sediment trap time series, Paleoceanography, 18(2), 1050, doi:10.1029/2002PA000846.

Anderson, D. M., W. L. Prell, and N. J. Barratt (1989), Estimates of sea-surface temperatures in the Coral Sea at the Last Glacial Maximum, Paleoceanography, 4(6), 615-627.

Andreasen, D. J., and A. C. Ravelo (1997), Tropical Pacific Ocean thermocline depth reconstructions for the Last Glacial Maximum, Paleoceanography, 12(3), 395-413.

Andreasen, D. H., A. C. Ravelo, and A. J. Broccoli (2001), Remote forcing at the Last Glacial Maximum in the tropical Pacific Ocean, J. Geophys. Res., 106(C1), 879-897.
Bard, E. (1998), Geochemical and geophysical implications of the radiocarbon calibration, Geochem. Cosmochim. Acta, 62(12), 20252038.

Barker, S., M. Greaves, and H. Elderfield (2003), A study of cleaning procedures used for foraminiferal $\mathrm{Mg} / \mathrm{Ca}$ paleothermometry, Geochem. Geophys. Geosyst., 4(9), 8407 , doi:10.1029/2003GC000559.

Barrows, T. T., and S. Juggins (2005), Seasurface temperatures around the Australian margin and Indian Ocean during the Last Glacial Maximum, Quat. Sci. Rev., 24, 1017-1047.

Beaufort, L., T. de Garidel-Thoron, A. C. Mix, and N. G. Pisias (2001), ENSO-like forcing on oceanic primary production during the late Pleistocene, Science, 293, 2440-2444.
Bemis, B. E., H. J. Spero, J. Bijma, and D. W. Lea (1998), Reevaluation of the oxygen isotopic composition of planktonic foraminifera: Experimental results and revised paleotemperature equations, Paleoceanography, 13(2), $150-160$.

Bentaleb, I., M. Fontugne, and L. Beaufort (2002), Long-chain alkenones and $\mathrm{Uk}^{\prime} 37$ variability along a south-north transect in the western Pacific Ocean, Global Planet. Change, 34, 173-183.

Benway, H. M., B. A. Haley, G. P. Klinkhammer, and A. C. Mix (2003), Adaptation of a flowthrough leaching procedure for $\mathrm{Mg} / \mathrm{Ca} \mathrm{pa}-$ leothermometry, Geochem. Geophys. Geosyst., 4(2), 8403, doi:10.1029/2002GC000312. 
Berger, W. H. (1971), Sedimentation of planktonic foraminifera, Mar. Geol., 11, 325358.

Billups, K., and D. P. Schrag (2000), Surface ocean density gradients during the Last Glacial Maximum, Paleoceanography, 15, 110-123.

Boyle, E. A., and L. D. Keigwin (1985), Comparison of Atlantic and Pacific paleochemical records for the last 250,000 years: Changes in deep ocean circulation and chemical inventories, Earth Planet. Sci. Lett., 76, 135-150.

Broecker, W. S., and T.-H. Peng (1982), Tracers in the Sea, 690 pp., Eldigio, Lamont-Doherty Earth Obs., Palisades, N. Y

Brown, S. J., and H. Eldefield (1996), Variations in $\mathrm{Mg} / \mathrm{Ca}$ and $\mathrm{Sr} / \mathrm{Ca}$ ratios of planktonic foraminifera caused by postdepositional dissolution: Evidence of shallow Mg-dependent dissolution, Paleoceanography, 11(5), 543-551.

Chen, M., Q. Li, F. Zheng, X. Tan, R. Xiang, and Z. Jian (2005a), Variations of the last glacial warm pool: Sea surface temperature contrasts between the open western Pacific and South China Sea, Paleoceanography, 20, PA2005, doi:10.1029/2004PA001057.

Chen, M. T. C. C. Huang, U. Pflaumann, C. Waelbroeck, and M. Kucera (2005b), Estimating glacial western Pacific sea-surface temperature: Methodological overview and data compilation of surface sediment planktic foraminifer faunas, Quat. Sci. Rev., 24, 1049-1062, doi:10.1016/j.quascirev.2004.07.013.

Clement, A. C., R. Seager, and M. A. Cane (1999), Orbital controls on the El Niño/Southern Oscillation and the tropical climate, Paleoceanography, 14(4), 441-456.

CLIMAP (1981), Seasonal reconstructions of the Earth's surface at the Last Glacial Maximum, Geol. Soc. Am. Map Chart Ser., MC-36.

Conkright, M., S. Levitus, T. O’Brien, T. Boyer, J. Anotonov, and C. Stephens (1998), World Ocean Atlas 1998 CD-ROM data set documentation, 16 pp., Natl. Ocean. Data Cent., Silver Spring, Md.

Conte, M., A. Thompson, D. Lesley, and R. P. Harris (1998), Genetic and physiological influences on the alkenone/alkenoate versus growth temperature relationship in Emiliania huxleyi and Gephyrocapsa oceanica, Geochim. Cosmochim. Acta, 62, 51-68.

Conte, M. H., J. C. Weber, L. L. King, and S. G. Wakeham (2001), The alkenone temperature signal in western North Atlantic surface waters, Geochim. Cosmochim. Acta, 65, 4275-4287.

Conte, M. H., M.-A. Sicre, C. Rühlemann, J. C. Weber, S. Schulte, D. Schulz-Bull, and T. Blanz (2006), Global temperature calibration of the alkenone unsaturation index $\left(\mathrm{U}_{37}^{\mathrm{K}^{\prime}}\right)$ in surface waters and comparison with surface sediments, Geochem. Geophys. Geosyst., 7, Q02005, doi:10.1029/2005GC001054.

Craig, H., W. S. Broecker, and D. W. Spencer (1982), GEOSECS Pacific Ocean Expedition, vol. 4, Sections and Profiles, U.S. Gov. Print. Off., Washington, D. C.

Dansgaard, W. (1964), Stable isotopes in precipitation, Tellus, 16, 436-468.

de Garidel-Thoron, T., Y. Rosenthal, F. Bassinot, and L. Beaufort (2005), Stable sea surface temperatures in the Western Pacific Warm Pool over the past 1.75 million years, Nature, 433, 294-298, doi:10.1038/nature03189.

Dekens, P. S., D. W. Lea, D. K. Pak, and H. J. Spero (2002), Core top calibration of $\mathrm{Mg} / \mathrm{Ca}$ in tropical foraminifera: Refining paleotemperature estimation, Geochem. Geophys. Geosyst., 3(4), 1022, doi:10.1029/2001GC000200.
Delcroix, T., and M. McPhaden (2002), Interannual sea surface salinity and temperature changes in the Western Pacific Warm Pool during 1992-2000, J. Geophys. Res., 107(C12), 8002, doi:10.1029/2001JC000862.

de Villiers, S. (2003), Dissolution effects on foraminiferal $\mathrm{Mg} / \mathrm{Ca}$ records of sea surface temperature in the western equatorial Pacific Paleoceanography, 18(3), 1070, doi:10.1029/ 2002PA000802.

Duplessy, J.-C., E. Bard, M. Arnold, N. J Shackelton, J. Duprat, and L. Labeyrie (1991), How fast did the ocean-atmosphere system run during the last deglaciation?, Earth Planet. Sci. Lett., 103, 27-40.

Elderfield, H., and G. Ganssen (2000), Past temperature and $\delta^{18} \mathrm{O}$ of surface ocean waters inferred from foraminiferal $\mathrm{Mg} / \mathrm{Ca}$ ratios, Nature, 405, 442-445.

Fairbanks, R. G., P. H. Wiebe, and A. W. H. Be (1979), Vertical distribution and isotopic composition of living planktonic foraminifera in the western North Atlantic, Science, 207, $61-63$

Fairbanks, R. G., M. N. Evans, J. L. Rubenstone, R. A. Mortlock, K. Broad, M. D. Moore, and C. D. Charles (1997), Evaluating climate indices and their geochemical proxies measured in corals, Coral Reefs, Suppl. S, 16, 93-100.

Fedorov, A. V., and S. G. Philander (2000), Is El Niño changing?, Science, 288, 1997-2002.

Feldberg, M. J., and A. C. Mix (2003), Planktonic foraminifera, sea surface temperatures, and mechanisms of oceanic change in the Peru and south equatorial currents, $0-150 \mathrm{ka} \mathrm{BP}$ Paleoceanography, 18(1), 1016, doi:10.1029/ 2001PA000740.

Gagan, M. K., L. K. Ayliffe, D. Hopley, J. A Cali, G. E. Mortimer, J. Chappell, M. T McCulloch, and J. Head (1998), Temperature and surface-ocean water balance of the midHolocene tropical western Pacific, Science, $279,1014-1018$

Hagino, K., H. Okada, and H. Matsuoka (2000), Spatial dynamics of coccolithophore assemblages in the equatorial western-central Pacific Ocean, Mar. Micropaleontol., 39, 53-72.

Halpert, M. S., and C. F. Ropelewski (1992), Surface temperature patterns associated with the Southern Oscillation, J. Clim., 5, 577-593.

Hemleben, C., M. Spindler, and O. R. Anderson (1989), Modern Planktonic Foraminifera, 363 pp., Springer, New York.

Hewitt, C. D., R. J. Stouffer, A. J. Broccoli, J. F. B. Mitchell, and P. J. Valdes (2003), The effect of ocean dynamics in a coupled GCM simulation of the Last Glacial Maximum, Clim. Dyn. $20(2-3), 203-218$

Hoffmann, G., and M. Heimann (1997), Water isotope modeling in the Asian monsoon region, Quat. Int., 37, 115-128.

Hostetler, S. W., and P. U. Clark (2000), Tropical climate at the Last Glacial Maximum inferre from glacier mass-balance modeling, Science, $290,1747-1750$

Hostetler, S. W., and A. C. Mix (1999), Reassessment of ice-age cooling of the tropical ocean and atmosphere, Nature, 399, 673-676.

Imbrie, J. and N. G. Kipp (1971), A new micropaleontological method for quantitative paleoclimatology: Application to a late Pleistocene Caribbean core, in The Late Cenozoic Glacial Ages, edited by K. K. Turekian, pp. 71-181, Yale Univ. Press, New Haven, Conn.

Kawahata, H., A. Nishimura, and M. K. Gagan (2002), Seasonal change in foraminiferal production in the western equatorial Pacific warm pool: Evidence from sediment trap experi- ments, Deep Sea Res., Part II, 49(13-14), $2783-2800$

Kim, S. J., G. M. Flato, and G. J. Boer (2003), A coupled climate model simulation of the Last Glacial Maximum, part 2: Approach to equilibrium, Clim. Dyn., 20(6), 635-661.

Klinkhammer, G. P., B. A. Haley, A. C. Mix, H. M. Benway, and M. Cheseby (2004), Evaluation of automated flow-through timeresolved analysis of foraminifera for $\mathrm{Mg} / \mathrm{Ca}$ paleothermometry, Paleoceanography, 19 PA4030, doi:10.1029/2004PA001050.

Koutavas, A., J. Lynch-Stieglitz, T. M. Marchitto, and J. P. Sachs (2002), El Niño-like pattern in ice age tropical Pacific sea surface temperature, Science, 297, 226-230.

Lambeck, K., and J. Chappell (2001), Sea-level change through the last glacial cycle, Science, 292, 679-686.

Lea, D. W., T. A. Mashiotta, and H. J. Spero (1999), Controls on magnesium and strontium uptake in planktonic foraminifera determined by live culturing, Geochim. Cosmochim. Acta, 63, 2369-2379.

Lea, D. W., D. K. Pak, and H. J. Spero (2000) Climate impact of late Quaternary equatorial Pacific sea surface temperature variations, Science, 289, 1719-1724.

Martinez, J. I., P. De Deckker, and A. R. Chivas (1997), New estimates for salinity changes in the Western Pacific Warm Pool during the Last Glacial Maximum: Oxygen-isotope evidence, Mar. Micropaleontol., 32, 311-340.

McClymont, E. L., and A. Rosell-Mele (2005), Links between the onset of modern Walker circulation and the mid-Pleistocene climate transition, Geology, 33(5), 389-392.

McConnell, M. C., and R. C. Thunell (2005), Calibration of the planktonic foraminiferal $\mathrm{Mg} / \mathrm{Ca}$ paleothermometer: Sediment trap results from the Guaymas Basin, Gulf of California, Paleoceanography, 20, PA2016, doi:10.1029/2004PA001077.

Mix, A. C., A. E. Morey, N. G. Pisias, and S. W. Hostetler (1999), Foraminiferal faunal estimates of paleotemperature: Circumventing the no-analog problem yields cool ice age tropics, Paleoceanography, 14(3), 350-359.

Mix, A. C., E. Bard, and R. Schneider (2001), Environmental processes of the ice age: Land, oceans, glaciers (EPILOG), Quat. Sci. Rev., $20,627-657$

Moore, T. C., L. H. Burckle, K. Geitzenauer, B. Luz, A. Molina-Cruz, C. S. J. H. Robertson, H. Sachs, J. Theide, P. Thompson, and C. Wenham (1980a), The reconstruction of sea surface temperatures in the Pacific Ocean of $18,000 \mathrm{BP}$, Mar. Micropal., 5, 215-247.

Moore, T. C. J., L. H. Burckle, K. Geitznauer, B. Luz, A Molina-Cruz, J. H. Robertson, H. Sachs, C. Sancetta, J. Thiede, P. Thompson, and C. Wenkam (1980b), The reconstruction of sea surface temperatures in the Pacific Ocean of 18, 000 B. P., Mar. Micropaleontol., 5, $215-$ 247.

Morey, A. E., A. C. Mix, and N. G. Pisias (2005), Planktonic foraminiferal assemblages preserved in surface sediments correspond to multiple environment variables, Quat. Sci. Rev., 24, 925-950.

Muller, P. J., G. Kirst, G. Ruhland, I. von Storch, and A. Rosell-Mele (1998), Calibration of the alkenone paleotemperature index $\mathrm{U}_{37}^{\mathrm{K}^{\prime}}$ based on core-tops from the eastern South Atlantic and the global ocean $\left(60^{\circ} \mathrm{N}-60^{\circ} \mathrm{S}\right)$, Geochim. Cosmochim. Acta, 62, 1757-1772.

Nürnberg, D., J. Bijma, and C. Hemleben (1996), Assessing the reliability of magnesium in for- 
aminiferal calcite as a proxy for water mass temperature, Geochim. Cosmochim. Acta, 60, $803-814$.

Ohkouchi, N., K. Kawamura, T. Nakamura, and A. Taira (1994), Small changes in the sea surface temperature during the last 20,000 years: Evidence from the western tropical Pacific, Geophys. Res. Lett., 21(20), 2207-2210.

Palmer, M. R., and P. N. Pearson (2003), A 23,000-year record of surface water $\mathrm{pH}$ and $\mathrm{PCO} 2$ in the western equatorial Pacific Ocean, Science, 300, 480-482.

Pelejero, C., and E. Calvo (2003), The upper end of the $\mathrm{U} \mathrm{K}^{\prime} 37$ temperature calibration revisited, Geochem. Geophys. Geosyst., 4(2), 1014, doi:10.1029/2002GC000431.

Pierrehumbert, R. T. (2000), Climate change and the tropical Pacific: The sleeping dragon wakes, Proceedings of the National Academy of Sciences, 97(4), 1355-1358.

Porter, S. (2001), Snowline depression in the tropics during the Last Glaciation, Quat. Sci. Rev., 20, 1067-1091.

Prahl, F. G., L. A. Melhausen, and D. L. Zahnle (1988), Further evaluation of long-chain alkenones as indicators of paleoceanographic conditions, Geochim. Cosmochim. Acta, 52, 2303-2310.

Prentice, M. L., G. S. Hope, K. Maryunani, and J. A. Peterson (2005), An evaluation of snowline data across New Guinea during the last major glaciation, and area-based glacier snowlines in the Mt. Jaya region of Papua, Indonesia, during the Last Glacial Maximum, Quaternary International, 138139, 93-117.

Ropelewski, C. F., and M. S. Halpert (1989), Precipitation patterns associated with the high index phase of the Southern Oscillation, J. Clim., 2, 268-284.

Rosell-Mélé, A., et al. (2001), Precision of the current methods to measure the alkenone proxy UK $37^{\prime}$ and absolute abundance in sediments: Results of an interlaboratory comparison study, Geochem. Geophys. Geosyst., 2(7), doi:10.1029/2000GC000141.

Rosenthal, Y., and G. P. Lohmann (2002), Accurate estimation of sea surface temperatures using dissolution-corrected calibrations for $\mathrm{Mg} / \mathrm{Ca}$ paleothermometry, Paleoceanography, 17(3), 1044, doi:10.1029/2001PA000749.

Rosenthal, Y., F. Field, and R. M. Sherrell (1999), Precise determination of element/ calcium ratios in calcareous samples using Sector Field Inductively Coupled Plasma Mass Spectrometry, Anal. Chem., 71, 3248-3253.

Rosenthal, Y., G. P. Lohmann, K. C. Lohmann, and R. M. Sherrell (2000), Incorporation and preservation of $\mathrm{Mg}$ in Globigerinoides sacculifer: Implications for reconstructing the temperature and ${ }^{18} \mathrm{O} /{ }^{16} \mathrm{O}$ of seawater, Paleoceanography, 15(1), 135-145.

Rosenthal, Y., D. W. Oppo, and B. K. Linsley (2003), The amplitude and phasing of climate change during the last deglaciation in the Sulu Sea, western equatorial Pacific, Geophys. Res. Lett., 30(8), 1428, doi:10.1029/2002GL016612.

Rosenthal, Y., et al. (2004), Interlaboratory comparison study of $\mathrm{Mg} / \mathrm{Ca}$ and $\mathrm{Sr} / \mathrm{Ca}$ measurements in planktonic foraminifera for paleoceanographic research, Geochem. Geophys. Geosyst., 5, Q04D09, doi:10.1029/ $2003 \mathrm{GC} 000650$.

Schmidt, G. A. (1999), Error analysis of paleosalinity calculations, Paleoceanography, 14(3), $422-429$.

Schulte, S., and E. Bard (2003), Past changes in biologically mediated dissolution of calcite above the chemical lysocline recorded in Indian Ocean sediments, Quat. Sci. Rev., 22, 1757-1770.

Shin, S. I., Z. Liu, B. Otto-Bliesner, E. C. Brady, J. E. Kutzbach, and S. P. Harrison (2003), A simulation of the Last Glacial Maximum climate using the NCAR-CCSM, Clim. Dyn., 20(2-3), 127-151.

Sonzogni, C., E. Bard, F. Rostek, R. Lafont, A. Rosell-Mele, and G. Eglinton (1997), Core-top calibration of the alkenone index vs sea surface temperature in the Indian Ocean, Deep Sea Res., Part II, 44(6-7), 1445-1460. Spero, H. J., K. M. Mielke, E. M. Kalve, D. W. Lea, and D. K. Pak (2003), Multispecies approach to reconstructing eastern equatorial $\mathrm{Pa}$ cific thermocline hydrography during the past 360 kyr, Paleoceanography, 18(1), 1022, doi:10.1029/2002PA000814

Stott, L., C. Poulsen, S. Lund, and R. Thunell (2002), Super ENSO and global climate oscillations at millennial time scales, Science, 297, $222-226$.

Stott, L., K. Cannariato, R. Thunell, G. H. Haug, A. Koutavas, and S. Lund (2004), Decline of surface temperature and salinity in the western tropical Pacific Ocean in the Holocene epoch, Nature, 431, 56-59.
Thevenon, F., E. Bard, D. Williamson, and L. Beaufort (2004), A biomass burning record from the west equatorial Pacific over the last 360 ky: Methodological, climatic and anthropic implications, Palaeogeogr. Palaeoclimatol. Palaeoecol., 213(1)-(2), 83-99.

Visser, K., R. C. Thunell, and L. Stott (2003), Magnitude and timing of temperature change in the Indo-Pacific warm pool during deglaciation, Nature, 421, 152-155.

Waelbroeck, C., L. Labeyrie, E. Michel, J.-C. Duplessy, J. McManus, K. Lambeck, E. Balbon, and M. Labracherie (2002), Sea-level and deep water temperature changes derived from benthic foraminifera isotopic records, Quat. Sci. Rev. 21, 295-305

Wang, L. J. (2000), Isotopic signals in two morphotypes of Globigerinoides ruber (white) from the South China Sea: Implications for monsoon climate change during the last glacia cycle, Palaeogeogr. Palaeoclimatol. Palaeoecol., 161(3-4), 381-394.

Wang, Y. J., H. Cheng, R. L. Edwards, Z. S. An J. Y. Wu, C.-C. Shen, and J. A. Dorale (2001), A high-resolution absolute-dated late Pleistocene monsoon record from Hulu Cave, China, Science, 294, 2345-2348

Webster, P. J., V. O. Magaña, T. N. Palmer, J. Shukla, R. A. Tomas, M. Yanai, and T. Yasunari (1998), Monsoons: Processes, predictability, and the prospects for prediction, J. Geophys. Res., 103(C7), 14,45114,510

Yin, J. H., and D. S. Battisti (2001), The importance of tropical sea surface temperature patterns in simulations of Last Glacial Maximum climate, J. Clim., 14, 565-581.

E. Bard, L. Beaufort, T. de Garidel-Thoron, and C. Sonzogni, CEREGE, CNRS, AixMarseille Université-Europôle Méditerranéen de l'Arbois, F-13545 Aix-en-Provence Cedex, France. (garidel@cerege.fr)

A. C. Mix, College of Oceanography and Atmospheric Sciences, Oregon State University, Corvallis, OR 97331, USA.

Y. Rosenthal, Institute of Marine and Coastal Sciences, Rutgers the State University of New Jersey, 71 Dudley Road, New Brunswick, NJ 08901, USA. 